\title{
Heparan sulfate proteoglycans mediate $A \beta$ - induced oxidative stress and hypercontractility in cultured vascular smooth muscle cells
}

Matthew R. Reynolds ${ }^{1 \dagger}$, Itender Singh ${ }^{1 \dagger}$, Tej D. Azad ${ }^{1}$, Brandon B. Holmes ${ }^{2}$, Phillip B. Verghese ${ }^{2}$, Hans H. Dietrich', Marc Diamond ${ }^{3}$, Guojun Bu ${ }^{4}$, Byung Hee Han ${ }^{5}$ and Gregory J. Zipfel ${ }^{1,2^{*}}$

\begin{abstract}
Background: Substantial evidence suggests that amyloid- $\beta(A \beta)$ species induce oxidative stress and cerebrovascular (CV) dysfunction in Alzheimer's disease (AD), potentially contributing to the progressive dementia of this disease. The upstream molecular pathways governing this process, however, are poorly understood. In this report, we examine the role of heparan sulfate proteoglycans (HSPG) in Aß-induced vascular smooth muscle cell (VSMC) dysfunction in vitro.

Results: Our results demonstrate that pharmacological depletion of HSPG (by enzymatic degradation with active, but not heat-inactivated, heparinase) in primary human cerebral and transformed rat VSMC mitigates $A \beta_{1-40^{-}}$and $A \beta_{1-42}$-induced oxidative stress. This inhibitory effect is specific for HSPG depletion and does not occur with pharmacological depletion of other glycosaminoglycan (GAG) family members. We also found that $A \beta_{1-40}$ (but not $A \beta_{1-42}$ ) causes a hypercontractile phenotype in transformed rat cerebral VSMC that likely results from a HSPGmediated augmentation in intracellular $\mathrm{Ca}^{2+}$ activity, as both $A \beta_{1-40}$-induced VSMC hypercontractility and increased $\mathrm{Ca}^{2+}$ influx are inhibited by pharmacological HSPG depletion. Moreover, chelation of extracellular $\mathrm{Ca}^{2+}$ with ethylene glycol tetraacetic acid (EGTA) does not prevent the production of $A \beta_{1-40^{-}}$or $A \beta_{1-42^{-}}$ mediated reactive oxygen species (ROS), suggesting that A $\beta$-induced ROS and VSMC hypercontractility occur through different molecular pathways.
\end{abstract}

Conclusions: Taken together, our data indicate that HSPG are critical mediators of A $\beta$-induced oxidative stress and $A \beta_{1-40}$-induced VSMC dysfunction.

Keywords: Heparan sulfate proteoglycans, Alzheimer's disease, Vascular smooth muscle cells, Cerebrovascular dysfunction, Reactive oxygen species, Oxidative stress, Heparinase, Heparin

\footnotetext{
*Correspondence: zipfelg@wustl.edu

${ }^{\dagger}$ Equal contributors

'Department of Neurological Surgery, Washington University School of

Medicine, Hope Center Program on Protein Aggregation and

Neurodegeneration, Charles F. and Joanne Knight Alzheimer's Disease

Research Center, Campus Box 8057, 660 South Euclid Avenue, St. Louis,

Missouri 63110, USA

${ }^{2}$ Department of Neurology, Washington University School of Medicine, Hope

Center Program on Protein Aggregation and Neurodegeneration, Charles F.

and Joanne Knight Alzheimer's Disease Research Center, St. Louis, Missouri,

USA

Full list of author information is available at the end of the article
} 


\section{Background}

Alzheimer's disease (AD) is a progressive amnestic dementia characterized by the deposition of $A \beta$ peptides within the brain parenchyma and cerebrovasculature [1]. While the mechanisms underlying the development and progression of $\mathrm{AD}$ remain enigmatic, a growing body of evidence indicates that the pathologic effects of $A \beta$ on cerebral vessels likely play a critical role (for review, see Ref. [2]). Specifically, soluble and insoluble forms of A $\beta$ have been shown to impair CV autoregulation [3-6], reduce cerebral blood flow (CBF) $[3,7,8]$, and exacerbate ischemic infarction [9-11]-deleterious effects that are thought to contribute to the progressive dementia of AD. Understanding the mechanisms of these $A \beta$-induced CV deficits is therefore essential to guide development of novel therapies.

Multiple lines of evidence indicate that $\mathrm{A} \beta$-induced $\mathrm{CV}$ deficits are mediated by reactive oxygen species (ROS) (for review, see Ref. [12]). For instance, we have shown that application of exogenous, soluble $A \beta\left(A \beta_{1-40}\right.$ and $A \beta_{1-42}$ monomers) onto isolated mouse cerebral arterioles leads to significant oxidative stress and vasomotor dysfunction, and that anti-ROS strategies markedly improve these CV deficits [13]. Others have shown that exogenous $A \beta$ monomers applied to the pial surface of live mice cause significant oxidative stress and CV dysfunction, both of which can be attenuated via a variety of anti-ROS interventions [14-16]. Young Tg2576 mice having elevated levels of endogenous soluble $A \beta$ species display substantial oxidative stress and $\mathrm{CV}$ deficits, both of which can be inhibited by genetically eliminating the catalytic subunit Nox2 of NADPH oxidase (nicotinamide adenine dinucleotide phosphate-oxidase - a major source of ROS in cerebral vessels) [17]. Fibrillar $A \beta$ in the form of cerebral amyloid angiopathy (CAA) has also been shown to promote CV dysfunction via ROS. First, Garcia-Alloza et al. [18] observed that CAA-laden vessels (but not CAA-free vessels) of aged Tg2576 mice develop severe oxidative stress. Second, Park et al. [19] found that aged $\operatorname{Tg} 2576$ mice lacking the Nox2 subunit of NADPH oxidase develop less oxidative stress and no CV deficits compared to age-matched control Tg2576 mice. Though the presence of CAA and its effect on vessel function was not specifically examined in this study, the fact that Tg2576 mice were assessed at an age when CAA is expected [20] suggested that NADPH oxidase-derived ROS may also contribute to CAA-induced CV deficits. Third, we recently reported that administration of the NADPH oxidase inhibitor, apocynin, or the free radical scavenger, tempol, to aged Tg2576 mice significantly improves CV dysfunction and does so by decreasing CAA-induced vasomotor impairment as well as reducing CAA formation itself [21]. As such, modulation of ROS and identification of the upstream inducers of $A \beta$-mediated ROS production will be instrumental for designing novel therapies to prevent $\mathrm{A} \beta$-induced $\mathrm{CV}$ dysfunction and the impact these vascular deficits have on AD dementia.

Heparan sulfate proteoglycans (HSPG) are an attractive upstream target of $\mathrm{A} \beta$-induced ROS production and $\mathrm{CV}$ dysfunction. HSPG are complex macromolecules involved in diverse biological processes and are ubiquitously present on the cell surface and in the extracellular matrix [22]. Immunohistochemical studies of post-mortem AD brain suggest that HSPG are associated with the hallmark $A \beta$ pathologies and correlate temporally with $A \beta$ deposition $[23,24]$. In vitro experiments demonstrate that HSPG promote A $\beta$ aggregation [25], stabilize $A \beta$ fibrils [26], and inhibit A $\beta$ degradation [26]. HSPG bind $A \beta$ with high affinity and promote its intracellular uptake in multiple cell types [27], including human cerebral vascular smooth muscle cells (VSMC) [28]. In addition, pharmacological and/or genetic depletion of HSPG prevents the intracellular uptake of $A \beta$ and resultant deposition both in vitro [29] and in vivo [30]. These findings implicate HSPG as a key contributor to $A \beta$ metabolism and fibrillogenesis and suggest that it may play a key role in ultimately the development of AD. The role of HSPG in A $\beta$-induced ROS production and $\mathrm{CV}$ dysfunction, however, has yet to be examined.

To date, most studies examining the mechanisms of $\mathrm{A} \beta$-induced $\mathrm{CV}$ deficits have focused on the deleterious interaction of $A \beta$ on vascular endothelial cells (VEC) (for review see Ref. [31]). Specifically, A $\beta$ has been shown to induce VEC dysfunction, leading to decreased production of nitric oxide (NO; a potent endothelialderived vasodilator) and vascular hypercontractility [17]. Several studies, however, have shown that VSMC dysfunction also plays a causal role in $\mathrm{A} \beta$-induced $\mathrm{CV}$ deficits, as enhanced ATP-induced constriction (an VEC-independent response) was noted in isolated mouse cerebral arterioles exposed to exogenous $A \beta$ monomers [13] and impaired responses to the VEC-independent vasodilator SNAP was documented in young Tg2576 mice having elevated levels of endogenous soluble $\mathrm{A} \beta$ (but no CAA) [6, 17]. Moreover, given the location of fibrillar $A \beta$ within the abluminal portion of the tunica media surrounding VSMC in CAA-laden vessels [32, 33], the VSMC architectural changes and frank cell death that occurs in vessels with CAA deposits $[6,34]$. The expectation that markedly elevated levels of soluble $A \beta$ species reside in close proximity to CAA deposits within the perivascular space [35], it is likely that VSMC dysfunction plays an even greater role in CAA-induced CV deficits. We therefore focused our experiments on VSMC as the target of $A \beta$-mediated toxic effects in an effort to elucidate 
the upstream molecular events leading NADPH oxidase activation, ROS production, and vascular cell dysfunction.

\section{Methods \\ Reagents}

$A \beta$ peptides $\left(A \beta_{1-40}, A \beta_{40-1}\right.$, and $\left.A \beta_{1-42}\right)$ were purchased from American Peptide Company (Sunnyvale, CA), reconstituted in purified water, snap frozen over liquid nitrogen and immediately utilized or stored at $-80{ }^{\circ} \mathrm{C}$ for no longer than two weeks prior to use. Chondroitinase B and $\mathrm{AC}$ were purchased from IBEX Technologies Inc. (Montreal, Quebec, Canada). Purified receptor-associated protein (RAP) was a gift from Dr. Bu (Mayo Clinic, FL). All other reagents, including heparinase enzymes (I and III), were purchased from Sigma-Aldrich (St. Louis, MO).

\section{Antibodies}

The 82E1 (anti-Human A $\beta$ mouse monoclonal antibody), HJ2 (anti-human A $335-40$ ) and HJ5-1 (an antibody that selectively recognizes soluble, monomeric anti-human $A \beta$ ) monoclonal antibodies were a gift from Dr. Holtzman (Washington University in St. Louis, MO).

\section{Cell culture}

Primary human cerebral VSMC were purchased from ScienCell Research Laboratories (Carlsbad, CA) and grown according to the manufacturer's instructions. To confirm the data obtained from these cells, primary human cerebral VSMC from another source (Cell Biologics, Chicago, IL) were also used. All human VSMC used in the present study were APOE e3/e3 allele. Transformed rat cerebral VSMC were also used, which were kindly provided by Dr. Diglio, Wayne State University, MI) $[36,37]$. Rat cerebral VSMC were grown in Dulbecco's modified eagle's medium (DMEM) supplemented with $10 \%$ fetal bovine serum (FBS), $100 \mathrm{U} / \mathrm{mL}$ penicillin, and $100 \mu \mathrm{g} / \mathrm{mL}$ streptomycin sulfate. Rat VSMC cell line was established from long-term serial cultures of adult rat brain VSMC (mainly small pial arteries and arterioles). The cell line has phenotypical and immunohistochemical characteristics of VSMC. These cells were then infected with Schmidt-Ruppin Rous sarcoma virus-strain D, an arian retrovirus to induce immortality. This cell line has proven to be a useful model for studying the specialized biochemical and functional properties of these cells. Primary human cerebral VSMC cells were used at passages 4 and maintained at $37{ }^{\circ} \mathrm{C}$ in humidified air containing $5 \% \mathrm{CO}_{2}$.

\section{ROS assay}

Cells were plated onto 96-well black clear-bottomed plates (Corning Inc. Life Sciences, Tewksbury, MA) at a density of $50 \times 10^{3}$ cells/well the day prior to experiments. The day of experiments (cells density at near confluency), cells were washed gently for 10-15 seconds with warmed $\left(37^{\circ} \mathrm{C}\right.$ ) Leibovitz's media (L-15; no phenol red indicator), loaded with the ROS-sensitive dye Mitotracker Red $\mathrm{CM}-\mathrm{H}_{2} \mathrm{XRos}$ (MTR, final concentration of $5 \mu \mathrm{M}$; Molecular Probes, Eugene, OR) or dihydroethidium (DHE, final concentration of $10 \mu \mathrm{M}$; Molecular Probes) and incubated for 20-30 min. After incubation, cells were washed with warm L-15 media and freshly prepared $A \beta$ peptides (dissolved in L-15 media) were added immediately before measurements at room temperature. In some experiments, cells were co-treated with apocynin $(10 \mu \mathrm{M})$ and $A \beta_{1-40}(2 \mu \mathrm{M})$. Fluorescence was measured at room temperature with a plate reader (Synergy HTTR with KC4 software) over $30 \min \left(\lambda_{\mathrm{Ex}}=475\right.$ and $\lambda_{\mathrm{Em}}=645$ for MTR, and $\lambda_{E x}=520$ and $\lambda_{E m}=610$ for DHE).

In some experiments, cells were pre-incubated with heparin $(15 \mathrm{U} / \mathrm{mL})$, sodium chlorate $(5-50 \mathrm{mM})$, active or heat denatured (boiled at $100{ }^{\circ} \mathrm{C}$ for $20 \mathrm{~min}$ ) heparinase I (5 Sigma units/mL) and heparinase III (2 Sigma units $/ \mathrm{mL})$, chondroitinase $\mathrm{AC}\left(10^{-1} \mathrm{IU} / \mathrm{mL}\right)$, or chondroitinase $B\left(10^{-1} \mathrm{IU} / \mathrm{mL}\right)$ in growth media for $2 \mathrm{~h}$ prior to analysis. For neutralizing antibody experiments, cells were pre-incubated with antibody $(10 \mu \mathrm{g} / \mathrm{mL})$ in growth media for 2-3 h or co-treated with HJ5-1 antibody $(0.3 \mathrm{mg} / \mathrm{mL})$ and $A \beta_{1-40}(2 \mu \mathrm{M})$.

\section{Intracellular $\mathrm{Ca}^{2+}$ activity assay}

Human or rat VSMC were plated onto 96-well blackbottomed plates (Corning Inc. Life Sciences, Tewksbury, MA) at a density of $50 \times 10^{3}$ cells/well the day prior to the experiments. The day of experiments (cell density at near confluency), cells were washed with warmed $\left(37^{\circ} \mathrm{C}\right)$ L-15 media (no phenol red indicator), loaded with the Fura II $\mathrm{Ca}^{2+}$-sensitive dye (Invitrogen, Molecular Probes, Eugene, OR; $10 \mu \mathrm{M}$ ), and incubated at $37{ }^{\circ} \mathrm{Cfor} 20$ $30 \mathrm{~min}$. After incubation, cells were washed with L-15 media and freshly prepared $A \beta$ peptides (dissolved in L-15 media) were added immediately before measurements. In select experiments, cells were pre-treated with active or heat denatured (boiled at $100{ }^{\circ} \mathrm{C}$ for $20 \mathrm{~min}$ ) heparinase I (5 Sigma units $/ \mathrm{mL}$ ). In other experiments, either an Ltype $\mathrm{Ca}^{2+}$ channel antagonist (diltiazem or verapamil; $10 \mu \mathrm{M})$ or the $\mathrm{Ca}^{2+}$ chelator ethylene glycol tetraacetic acid (EGTA; $5 \mathrm{mM}$ ) was added to the extracellular media. The addition of ionomycin to each sample well (Sigma-Aldrich, St. Louis, MO; $2 \mu \mathrm{M}$ ) was used as a positive control for intracellular $\mathrm{Ca}^{2+}$ signal. Rat VSMC were also treated with aminoethoxydiphenyl borate (2APB, $10 \mu \mathrm{M})$, an IP3-receptor inhibitor or ryanodine (1H-Pyrrole-2-carboxylic acid, $10 \mu \mathrm{M}$ ), a Ryanodine receptor inhibitor.

The quantification of intracellular $\mathrm{Ca}^{2+}$ influx was performed using ratiometric measurements as previously described by Grynkiewicz et al. [38] with additional 
corrections for viscosity according to Poenie et al. [39] The $\mathrm{pH}$ sensitivity of Fura II $\mathrm{Ca}^{2+}$-sensitive dye was calculated using the method of Batlle et al. [40]. A detailed description of the calculations for these measurements can be found in our previous work [41].

\section{Analysis of $A \beta$ peptides}

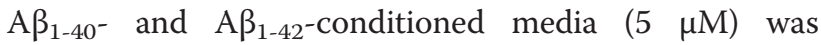
removed from human cerebral VSMC cultures after a 30 min incubation at $37^{\circ} \mathrm{C}$ and fractionated over a size exclusion column (Superdex 200 10/300; 1 mL/min; GE Healthcare Life Sciences, Piscataway, NJ) using fast performance liquid chromatography (FPLC). The eluted fractions were tested for the presence of $A \beta$ using an established enzyme-linked immunosorbent assay (ELISA) [42]. Fractions containing $A \beta$ peptide were further analyzed by sodium dodecyl sulfate (SDS) and native polyacrylamide gel electrophoresis (PAGE) and Western blotting.

\section{SDS- and native-PAGE}

For denaturing conditions, samples were boiled in Laemmli sample buffer (0.125 M Tris [pH 6.8], 4 \% SDS, $20 \%$ glycerol, and $10 \% \beta$-mercaptoethanol), loaded onto a 16.5 \% Tris-Tricine Criterion PreCast gel (BioRad Life Science, Hercules, CA), resolved electrophoretically, and transferred onto a nitrocellulose membrane. Membranes were boiled in phosphate buffered saline for $5 \mathrm{~min}$, blocked with a $5 \%(\mathrm{w} / \mathrm{v})$ solution of non-fat dry milk in tris buffered saline with tween (TBST), and then incubated for $16 \mathrm{~h}$ at $4{ }^{\circ} \mathrm{C}$ in a primary antibody solution $(82 \mathrm{E} 1 ; 1 \mu \mathrm{g} / \mathrm{mL})$. Following a secondary incubation with a HRP-conjugated goat anti-mouse antibody (Jackson ImmunoResearch, West Grove, PA), the membranes were processed using enhanced chemiluminescence (Clarity Western ECL Substrate; Biorad Life Science, Hercules, CA) and protein bands were detected using the G:BOX iChemi XT imaging system (Syngene, Frederick, MD). For native conditions, samples were mixed with NativePAGE sample buffer (Life Technologies, Carlsbad, CA), loaded onto a Novex 4-20 \% Tris-Glycine Native gel (Life Technologies, Carlsbad, CA), resolved electrophoretically, and transferred onto nitrocellulose membranes. The remainder of the procedure was analogous to that performed for denaturing conditions.

\section{Cell surface area assay}

Cells were grown in 48-well culture dishes, washed with warmed L-15 media, and images were acquired with an inverted light microscope (Nikon Eclipse E800; Nikon, Melville, NY). Following a $30-\mathrm{min}$ incubation at $37{ }^{\circ} \mathrm{C}$ with varying $A \beta$ preparations, additional light micrographs were obtained. In all instances, the experimenter who acquired the micrographs was blinded to the treatment conditions. All cells were then treated with warm L-15 media containing $100 \mathrm{mM}$ potassium chloride $(\mathrm{KCl})$ and cell surface area was measured at 1,3 , and 5 min after KCL addition, as described earlier [21]. Images were acquired from the same quadrant of each well (near the center of the dish) to minimize variations of cell layering at the culture dish periphery. All micrographs were processed using the Image J software package (National Institute of Health website; www.imagej.nih.gov) and cell surface area was quantified using the automatic threshold function. Data was analyzed as \% change in relative surface area units as compared to the vehicle-treated control cells.

\section{Immunoprecipitation of HSPG}

Human VSMC cells were grown to near confluency in $100 \mathrm{~mm}$ petri dishes and treated with $\mathrm{A} \beta_{1-40}(2 \mu \mathrm{M})$ or $A \beta_{40-1}(2 \mu \mathrm{M})$ for $30 \mathrm{~min}$. Cells were washed four times with HBSS and cells were lysed with RIPA buffer. Cell lysates were immunoprecipitated with anti-Heparan Sulphate Proteoglycan (Large) antibody (A7L6, Abcam). Samples were immunoprecipitated using a Protein G immunoprecipitation kit (Roche Applied Sciences, Indianapolis, IN) followed by SDS-PAGE separation and transfer onto nitrocellulose membranes (Millipore Corp). Immunoblotting was performed by incubating the membrane with mouse anti- $\mathrm{A} \beta$ antibody (6E10, Sigma). Following incubation the corresponding secondary goat-anti-Rabbit HRP-conjugated antibody (Santa Cruz Biotech) was used to detect immunoreactive product with chemiluminescent kit (BioRad).

\section{Quantitative Polymerase Chain Reaction (qPCR)}

Cells were grown to near confluency in 6-well plates, washed with PBS, and total RNA was isolated using Trizol reagent (Life Technologies, Carlsbad, CA) followed by synthesis of cDNA by reverse transcriptase using the High Capacity cDNA Reverse Transcriptase Kit (Applied Biosystems, Foster City, CA). Sense and antisense oligonucleotides were designed for each HSPG subtype (Additional file 1: Table S1) using a real-time PCR primer design tool (Integrated DNA Technologies, Coralville, IA). qPCR was performed using a 7500 real-time PCR System (Applied Biosystems, Foster City, CA) and the reactions were performed using SYBR Green PCR Master Mix reagents (Applied Biosystems, Foster City, CA). GAPDH expression was used as an internal loading control. Data were analyzed using the delta-delta calculation method to calculate fold change relative to controls [43].

\section{Statistics}

Determination of significance was accomplished by use of a student's two-tailed t test or ANOVA, depending on the design of the experiment. The level of statistical significance was set at 0.05 . 


\section{Results}

$A \beta_{1-40}$ and $A \beta_{1-42}$ induce ROS production via NADPH oxidase Previous reports have demonstrated that $A \beta$-induced ROS is a critical mediator of CV dysfunction in vitro [44], ex vivo [13], and in vivo [4-7, 17-19]. To examine the effects of $A \beta_{1-40}$ and $A \beta_{1-42}$ on ROS production in primary human cerebral VSMC, these cells were loaded with a fluorescent dye sensitive for detecting mitochondrial ROS (Mitotracker Red $\mathrm{CM}-\mathrm{H}_{2} \mathrm{XRos}$ ), treated with varying $A \beta$ preparations, and assayed for ROS production after $30 \mathrm{~min}$. We observed a dose-dependent increase in ROS with both $A \beta_{1-40}$ and $A \beta_{1-42}$ at micromolar, but not nanomolar, concentrations (Fig. 1a, b). Treatment with a scrambled control peptide $\left(A \beta_{40-1}\right)$ did not induce ROS production. Co-treatment of cells with $A \beta_{1-40}$ and the $\mathrm{NADPH}$ oxidase inhibitor apocynin reduced ROS generation to baseline levels. Interestingly, at each concentration, $A \beta_{1-42}$ was a more potent inducer of ROS than $A \beta_{1-40}$ in human cerebral VSMC (Fig. 1a, b). Apocynin is a non-specific inhibitor of Nox2. To more directly determine whether Nox2 is involved in $A \beta_{1-40}$ induced ROS production, we performed a targeted genetic knockdown experiment in human VSMC using si-Nox2. We found that genetic Nox2 inhibition significantly reduces $\mathrm{A} \beta_{1-40}$-induced ROS (Fig. 1c), which indicates a direct role of Nox2 in $A \beta_{1-40}$-induced ROS production.

Several additional control experiments were performed to determine the cellular consequences of $A \beta_{1-40}$-induced ROS production, to examine the impact of apocynin on baseline ROS production, and to assess the impact of physiological oxygen levels on $A \beta_{1-40}$-induced ROS production. To determine whether $A \beta_{1-40}$-induced ROS production produces toxic damage to cellular components, we quantified lipid oxidation levels following
$\mathrm{A} \beta_{1-40}$ treatment. Human VSMC were exposed to $A \beta_{1-40}$ for $24 \mathrm{~h}$, followed by assessment of lipid oxidation via measurement of thiobarbituric acid reactive substance (Additional file 2: Figure $\mathrm{S} 1$ ). We found that $\mathrm{A} \beta_{1-40}$ significantly increases lipid peroxidation - a finding consistent with true $A \beta_{1-40}$-induced oxidative stress. To assess whether apocynin impacts baseline ROS production in VSMC, we treated human VSMC with apocynin alone (without $\mathrm{A} \beta_{1-40}$ ) and found that baseline ROS levels were not impacted (Additional file 3: Figure S2). To determine if differing levels oxygen impact ROS production in $A \beta_{1-40}$ treated VSMC, we performed an experiment using $10 \%$ oxygen (conditions that are considered physiologic [45]) and an experiment using $1 \%$ oxygen (conditions that are hypoxic) and compared these results to our experiments where VSMCs were grown in humidified air containing $5 \% \mathrm{CO}_{2}$ (conditions that are not physiologic, but are very commonly used in the field [13]). We found that $A \beta_{1-40}$ induces significant ROS production in cultured VSMCs under both conditions, but that ROS production was greater with $10 \%$ oxygen (Additional file 4: Figure S3A) than $1 \%$ oxygen (Additional file 4: Figure S3B).

Given the tendency of monomeric $A \beta$ to polymerize into oligomers and fibrils over time, we analyzed VSMC conditioned media from the $A \beta_{1-40^{-}}$and $A \beta_{1-42^{-}}$-treated $(5 \mu \mathrm{M})$ samples after $30 \mathrm{~min}$ to assess higher order species. A $\beta$ species from VSMC conditioned media were loaded onto a size exclusion chromatography column and fractionated via FPLC. A $\beta$-containing fractions were detected using ELISA, and those fractions were further analyzed by SDS - and native-PAGE. We found that the majority of $A \beta_{1-40}$ was in monomeric form with minor amounts $(<10 \%)$ of higher order, SDS soluble aggregates

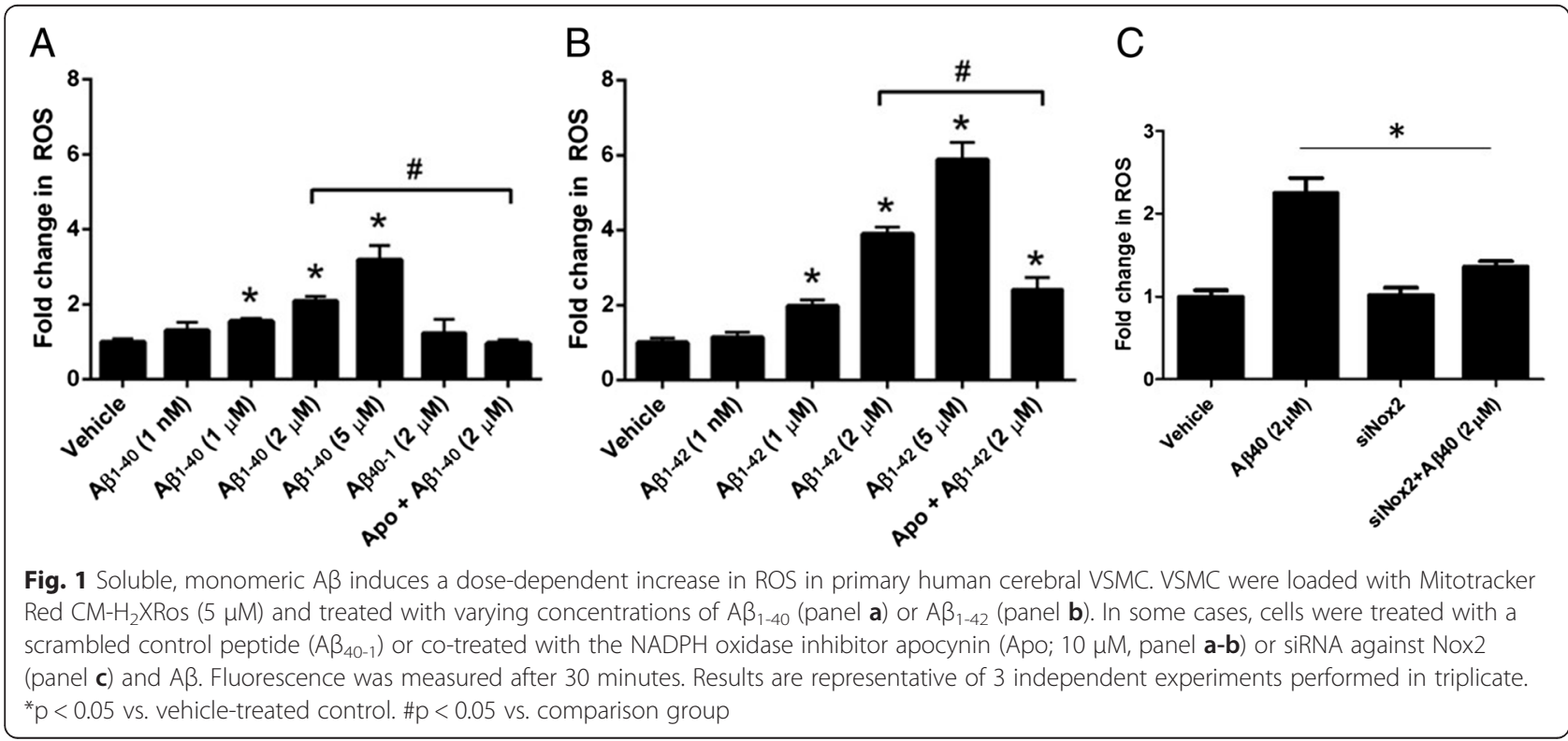


(Additional file 5: Figure S4A, B). Similarly, the $A \beta_{1-42}$ sample was mostly in monomeric form with minor amounts $(<15-20 \%)$ of higher order, SDS soluble aggregates (Additional file 5: Figure S4C, D). To specifically differentiate monomers vs. oligomers in the media, we utilized an oligomer-specific anti- $A \beta$ antibody (A11). We found that the majority of $A \beta$ remains as monomers in our experimental conditions; however, we do detect a very small amount of oligomers (Additional file 5: Figure S4E).

\section{$A \beta_{1-40}$-induced ROS production is attenuated by targeted inhibition of HSPG}

HSPG are present in both the extracellular matrix (agrin, perlecan, and collagen XVIII) and the cell surface (glypicans 1-6 and syndecans 1-4) [22]. To assess which HSPG subtypes are present in human cerebral and rat cerebral VSMC, we harvested RNA from cell culture lysates and quantified mRNA using qPCR. In human and rat cerebral VSMC, we found that while all HSPG subtype mRNAs were detectable, they were expressed to very different levels (Additional file 6: Figure S5A, B). While greater levels of agrin, perlecan, glypican 1 , syndecan 2 , syndecan 3 and keratan sulfate mRNA were present in human vs. rat VSMC, greater levels of collagen XVIII, glypican 3, glypican 4 , glypican 6 , syndecan 1 , syndecan 4 and chondroitin sulphate mRNA were present in rat vs. human VSMC. Given the known interaction of several HSPG subtypes with $A \beta[22,24]$, we hypothesized that HSPG could be involved in $\mathrm{A} \beta$-induced ROS production.

Low molecular weight heparin administration has previously been shown to prevent $A \beta$ internalization in cultured cells in vitro [29] and attenuate $A \beta$-mediated inflammation and neurotoxicity in vivo [46], likely through a HSPGdependent mechanism [47]. For this reason, we examined whether heparin could mitigate ROS production in cultured human cerebral VSMC. Given that heparin can directly bind $A \beta$ and also exhibits pleotropic cellular effects [48], cells were pre-treated with heparin $(15 \mathrm{U} / \mathrm{mL})$, washed, loaded with Mitotracker Red $\mathrm{CM}-\mathrm{H}_{2} \mathrm{XRos}$ dye, and treated with $A \beta_{1-40}(2 \mu \mathrm{M})$. We observed that heparin pre-treatment markedly reduced $A \beta$-mediated ROS production (Fig. 2a), suggesting a possible contributing role of HSPG.

To more directly implicate HSPG in A $\beta$-induced ROS production, we pre-treated cells with either active or heat denatured heparinase I ( 5 Sigma U/mL) and heparinase III ( 2 Sigma U/mL) followed by washout and ROS measurements. Heparinase is a mammalian endo- $\beta$ - $D$ glucuronidase that specifically cleaves heparan sulfate, thereby preventing $A \beta-H S P G$ interactions. We found that pre-incubation with active, but not heat inactivated, heparinase I and III significantly reduced $A \beta_{1-40}$-mediated ROS production (Fig. 2b). We documented similar results after repeating this experiment with VSMC from another source (Cell Biologics, Additional file 7: Figure S6). When these experiments were performed using the fluorescent dye dihydroethidium (DHE; a sensitive indicator of cytosolic superoxide oxygen species), we obtained comparable results (Fig. 2c), suggesting that $\mathrm{A} \beta$-mediated ROS production occurs in both the mitochondria and cytosol.

To determine if HSPG directly interact with $A \beta_{1-40}$, human VSMC cells were treated with $A \beta_{1-40}$ for 30 minutes and cell lysates were immunoprecipitated with anti-HSPG antibody and immunoblotted with anti-A $\beta$ antibody. Immunoblot showed the presence of $A \beta$ in immunoprecipitated fractions, which suggests direct interaction of $A \beta$ with HSPG (Fig. 2d).

When coupled with the aforementioned pharmacologic experiments targeting HSPG, these data provide further evidence that $A \beta_{1-40}$ plays a key role in mediating VSMC cellular dysfunction.

Finally, we pre-treated cells with increasing concentrations of sodium chlorate, which blocks proper sulfation of HSPG. We found that sodium chlorate reduces $A \beta$-induced oxidative stress in human VSMC in a dose-dependent fashion (Fig. 3b). This observation is likely caused by the inability of $A \beta_{1-40}$ to effectively interact with non-sulfated HSPG side chains.

In total, our results that $\mathrm{A} \beta$-mediated ROS production is attenuated by three separate HSPG-targeted interventions-heparin that competitively inhibits HSPG; heparinase I or heparanase III that cleave heparan sulfate moieties of HSPG; and sodium chlorate that inhibits sulfation of HSPG side chains-strongly indicate that HSPG are a key mediator of the vascular oxidative stress caused by $\mathrm{A} \beta$.

\section{$A \beta_{1-40}$-induced ROS production is unaffected by targeted inhibition of other glycosaminoglycan family members}

In theory, $A \beta$ could bind either HSPG or other surface proteins, such as chondroitin sulfate proteoglycans and dermatin sulfate proteoglycans. To examine whether enzymatic disruption of other glycosaminoglycan (GAG) family members affects $A \beta$-mediated ROS elaboration, we pre-treated human cerebral VSMC with active and heat denatured chondroitinase $B$ (which selectively degrades dermatin sulfate) and chondroitinase AC (which selectively degrades chondroitin sulfate) prior to washout and ROS assessment. Our results demonstrate that neither dermatin sulfate nor chondroitin sulfate participate in $A \beta$-mediated oxygen radical production (Fig. 3a), supporting the notion that $A \beta_{1-40}$ selectively interacts specifically with HSPG to promote oxidative stress. 

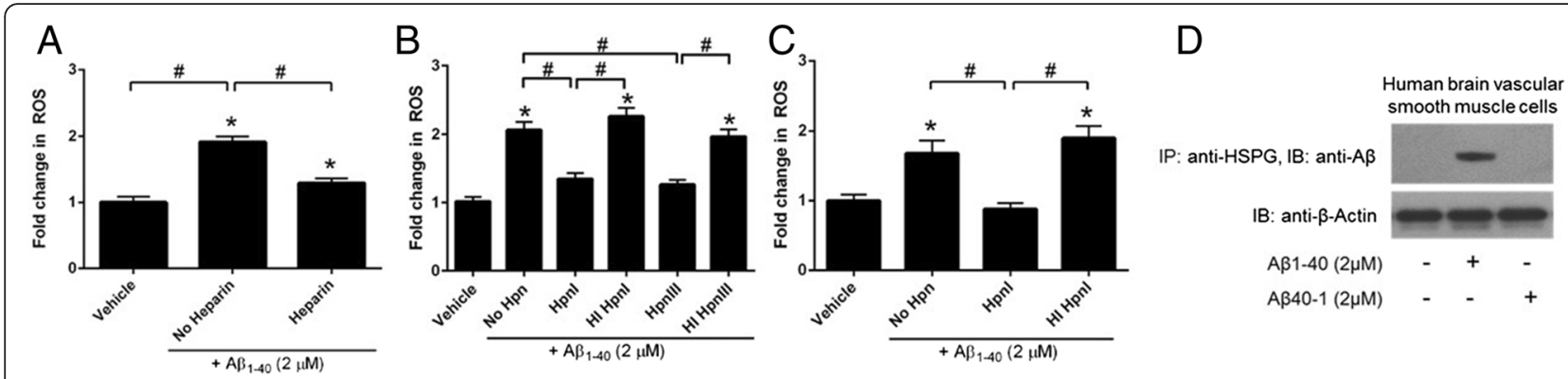

Fig. 2 Pharmacological knockdown of HSPG mitigates $A \beta_{1-40}$-induced mitochondrial and cytosolic ROS production in VSMC. Primary human cerebral VSMC were pre-treated with heparin ( $15 \mathrm{U} / \mathrm{mL}$ ), heparinase I (Hpnl; 5 Sigma U/mL), or heparinase III (HpnIIl; 2 Sigma U/mL) for 2 h, washed, loaded with Mitotracker Red $\mathrm{CM}-\mathrm{H}_{2} \mathrm{XRos}(\mathrm{MTR} ; 5 \mu \mathrm{M}$; panels $\mathbf{a}$, b) or the cytosolic superoxide-sensitive dye dihydroethidium (10 $\mu \mathrm{M}$; panel $\mathbf{c}$ ), washed, and treated with $A \beta_{1-40}$. In some cases, cells were pre-treated with heat-inactivated (HI) enzyme (at the same concentration of active enzyme) and washed prior to MTR loading and A $\beta$ treatment. Fluorescence was measured after 30 minutes. To determine if HSPG directly interact with $A \beta_{1-40}$, human VSMC cells were treated with $A \beta_{1-40}$ for 30 minutes and cell lysates were immunoprecipitated with anti-HSPG antibody and immunoblotted with anti-A $\beta$ antibody (Panel $\mathbf{d}$ ). Results are representative of 3 independent experiments performed in triplicate. ${ }^{*} \mathrm{p}<0.05 \mathrm{vs}$. vehicle-treated control. \#p<0.05 vs. comparison group

\section{$A \beta_{1-40}$-induced VSMC dysfunction is attenuated by} targeted inhibition of HSPG

Soluble, monomeric $A \beta$ is a vasoactive peptide that exhibits significant vasoconstrictive properties $[6,49,50]$. The preponderance of data suggests that $A \beta_{1-40}$-the species that primarily comprises the fibrillar deposits of CAA-is a more potent vasoconstrictor than $A \beta_{1-42}$ $[51,52]$. To delineate the effects of $A \beta$ treatment on cultured rat cerebral VSMC contractile function, cell surface area was measured after $30 \mathrm{~min}$ via light microscopy after treatment with varying $A \beta$ preparations. Of note, rat cerebral VSMC were used instead of human cells because we were unable to reliably quantitate changes in human cerebral VSMC morphology in response to various stimuli given their rigid adherence to the culture dish. However, we verified that rat cerebral VSMC are similar to human cerebral VSMC with respect to $A \beta_{1-40}$-induced ROS production and abrogation of $A \beta_{1-40}$-induced oxidative stress by pharmacological HSPG knockdown (Additional file 8: Figure S7A, B), though the magnitude of ROS production was different (likely the result of a species-specific effect).

In agreement with prior studies [21], we observed a $12 \%$ decrease in cell surface area following treatment with $A \beta_{1-40}$, but not with the $A \beta_{1-42}$ or $A \beta_{40-1}$ scrambled peptide (Fig. 4a). Also, co-treatment of cells with $A \beta_{1-40}$ and apocynin did not significantly change VSMC surface area relative to cells treated with $A \beta_{1-40}$ alone. This observation suggests that in rat cerebral VSMC, inhibition of ROS formation does not necessarily prevent $A \beta$ -
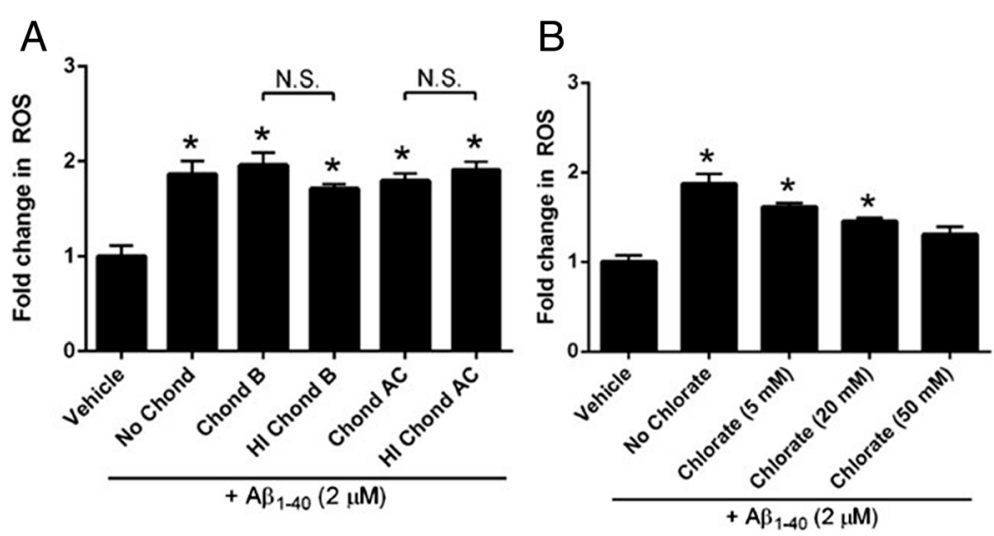

Fig. 3 Pharmacological knockdown of other glycosaminoglycan (GAG) family members does not affect A $\beta_{1-40}$-mediated ROS production in VSMC. Primary human cerebral VSMC were pre-treated with chondroitinase $B\left(10^{-1} \mathrm{IU} / \mathrm{mL}\right.$; selectively degrades dermatin sulfate; panel a), chondroitinase AC $\left(10^{-1} \mathrm{IU} / \mathrm{mL}\right.$; selectively degrades chondroitin sulfate; panel a), or varying concentrations of the sulfation inhibitor sodium chlorate (5-50 mM; panel b) for $2 \mathrm{~h}$, washed, loaded with Mitotracker Red $\mathrm{CM}_{-} \mathrm{H}_{2}$ XRos $(M T R ; 5 \mu \mathrm{M})$, and treated with $\mathrm{A} \beta_{1-40}$. In some cases, cells were pre-treated with heat-inactivated (HI) enzyme (at the same concentration of active enzyme) and washed prior to MTR loading and A $\beta$ treatment. Fluorescence was measured after 30 minutes. Results are representative of 3 independent experiments performed in triplicate. ${ }^{*} p<0.05$ vs. vehicle-treated control. \#p < 0.05 vs. comparison group 


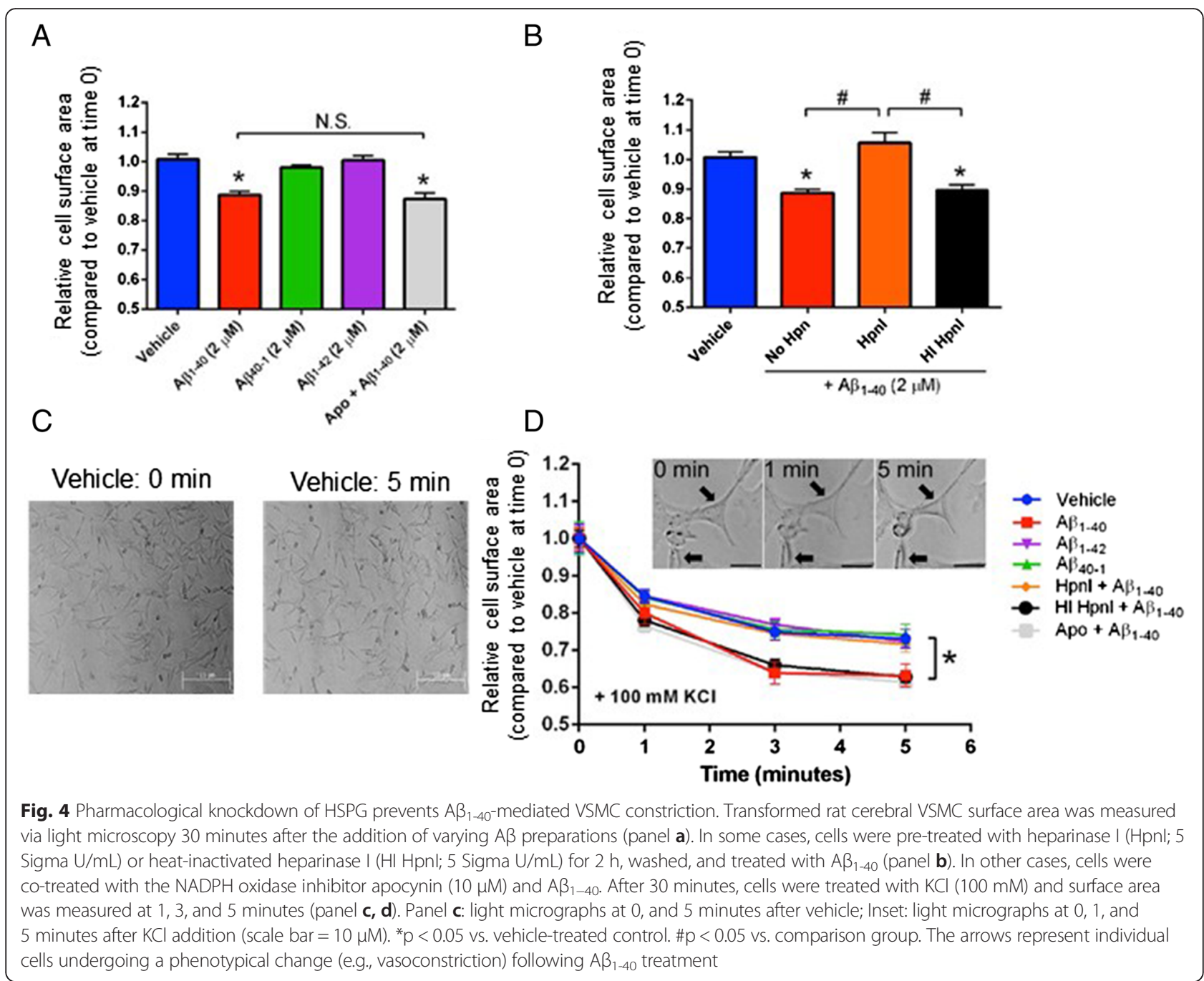

mediated VSMC constriction. Pre-incubation of cells with active-but not heat denatured-heparinase I enzyme (5 Sigma $\mathrm{U} / \mathrm{mL}$ ) followed by washout and treatment with $A \beta_{1-40}$ effectively reversed the $A \beta_{1-40}$-induced hypercontractile phenotype (Fig. 4b). After 30 minutes, cells were treated with $\mathrm{KCl}(100 \mathrm{mM})$ to open cell surface voltage-gated calcium channels [53] and VSMC surface area was measured over an additional 5 minutes. We found that VSMC initially treated with $A \beta_{1-40}$, apocynin $+A \beta_{1-40}$, and heat inactivated heparinase $I+A \beta_{1-40}$ all reduced VSMC surface area after $\mathrm{KCl}$ treatment relative to the vehicle-treated control at 3 and 5 minutes (Fig. 4c-d). Conversely, rat cerebral VSMC initially treated with $A \beta_{1-40}+$ heparinase I followed by treatment with $\mathrm{KCl}$ responded similarly to the vehicle-treated control at 3 and 5 minutes (Fig. 4c-d).

Potential role of $\mathrm{Ca}^{2+}$ in $\mathrm{A} \beta_{1-40}$-induced VSMC dysfunction To examine the role of $\mathrm{Ca}^{2+}$ in the regulation of $A \beta_{1-40^{-}}$ and $A \beta_{1-42}$-induced ROS production and $A \beta_{1-40}$-induced
VSMC hypercontractility, we utilized the $\mathrm{Ca}^{2+}$-sensitive dye Fura II to measure changes in intracellular $\mathrm{Ca}^{2+}$ levels. Rat cerebral VSMC were loaded with Fura II, washed, and then treated with varying concentrations of $\mathrm{A} \beta_{1-40}$ and $\mathrm{A} \beta_{1-42}$. We observed that intracellular $\mathrm{Ca}^{2+}$ influx increased as a function of $A \beta_{1-40}$ concentration over 10 minutes, with the maximum level of intracellular $\mathrm{Ca}^{2+}$ achieved after treatment with $\mathrm{A} \beta_{1-40}$ at $2 \mu \mathrm{M}$ concentrations (Fig. 5a). Interestingly, even at higher concentrations, the level of intracellular $\mathrm{Ca}^{2+}$ achieved after treatment of cells with $A \beta_{1-42}$ was well below that of cells treated with $A \beta_{1-40}$ (Fig. 5b). Co-treatment of rat cerebral VSMC with the NADPH oxidase inhibitor apocynin did not reverse $\mathrm{A} \beta_{1-40}$-mediated $\mathrm{Ca}^{2+}$ influx (Fig. 5c).

Next, we examined the route(s) by which $\mathrm{Ca}^{2+}$ enters the intracellular space following $A \beta_{1-40}$ treatment in VSMC. We found that $\mathrm{Ca}^{2+}$ does not enter through $\mathrm{L}$ type $\mathrm{Ca}^{2+}$ channels given that the L-type $\mathrm{Ca}^{2+}$ channel blockers verapamil and diltiazem did not decrease 

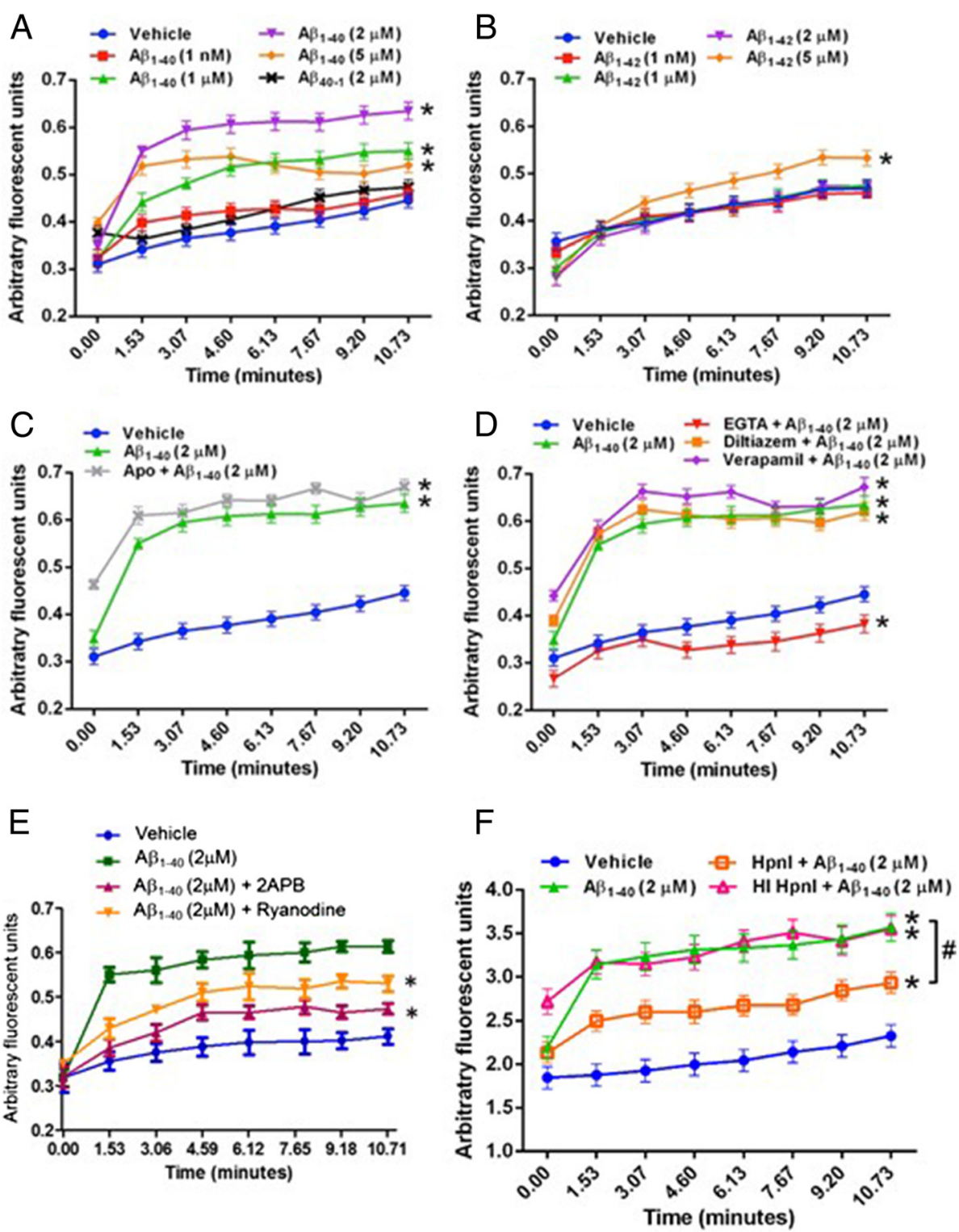

Fig. $5 \mathrm{~A} \beta_{1-40}$, but not $A \beta_{1-42}$, induces $\mathrm{Ca}^{2+}$ influx into VSMC and this $\mathrm{Ca}^{2+}$ influx does not occur through L-type $\mathrm{Ca}^{2+}$ channels. Transformed rat cerebral VSMC were loaded with fura II $(10 \mu \mathrm{M})$ and treated with varying concentrations of $A \beta_{1-40}$ (panel $\mathbf{a}$ ) or $A \beta_{1-42}$ (panel b). In some cases, cells were treated with a scrambled control peptide $\left(A \beta_{40-1}\right.$; panel a) or co-treated with the NADPH oxidase inhibitor apocynin $(A p o ; 10 \mu M)$ and $A \beta_{1-40}$ (panel c). In other experiments, cells were co-treated with an L-type Ca ${ }^{2+}$ channel antagonist (either verapamil or diltiazem; $10 \mu \mathrm{M}$ ) and $A \beta_{1-40}$, or treated with $A \beta_{1-40}$ in the presence or absence of the $\mathrm{Ca}^{2+}$ chelator EGTA (5 mM; panel d). Rat VSMC were also treated with aminoethoxydiphenyl borate $(2 \mathrm{APB}, 10 \mu \mathrm{M})$, an IP3-receptor inhibitor or ryanodine (1H-Pyrrole-2-carboxylic acid, $10 \mu \mathrm{M})$, a Ryanodine receptor inhibitor (panel e). In some experiments, cells were pre-treated with active or heat-inactivated heparinase I ( $\mathrm{Hpnl} ; 5$ Sigma U/mL), washed, loaded with fura II, and treated with $A \beta_{1-40}$ (panel f). Fluorescence was measured over $\sim 10$ minutes. Results are representative of 3 independent experiments performed in triplicate. ${ }^{*} p<0.05$ vs. vehicle-treated control

intracellular $\mathrm{Ca}^{2+}$, but co-incubation with the extracellular $\mathrm{Ca}^{2+}$ chelating agent EGTA produced a marked decrement in intracellular $\mathrm{Ca}^{2+}$ (Fig. 5d). We did find that 1) treatment with aminoethoxydiphenyl borate (2APB), an IP3-receptor inhibitor, decreased the $A \beta_{1-40}$-induced rise in intracellular $\mathrm{Ca} 2+$ (Fig. 5e) and 2) treatment with ryanodine (1H-Pyrrole-2-carboxylic acid), a Ryanodine receptor inhibitor, induced a small inhibition of the
$A \beta_{1-40}$-induced rise in intracellular Ca2+ (Fig. 5e). In total, these data indicate $A \beta_{1-40}$ treatment likely stimulates the release of $\mathrm{Ca} 2+$ into the intracellular space via IP-3 receptors. Non-specific $\mathrm{Ca} 2+$ entry through the cell membrane is also possible.

We also examined whether HSPG mediate the $\mathrm{Ca} 2+$ influx observed following $A \beta_{1-40}$ treatment in rat and human VSMC. We found that pre-incubation of rat 
cerebral VSMC with active, but not heat-inactivated, heparinase I attenuated $\mathrm{A} \beta_{1-40}$-induced $\mathrm{Ca}^{2+}$ influx (Fig. 5f). Using ratiometric quantification of intracellular $\mathrm{Ca}^{2+}$, we observed that treatment of rat cerebral VSMC with $A \beta_{1-40}$ $(2 \mu \mathrm{M})$ resulted in a $216.1 \pm 13.0 \mathrm{nM}$ increase in intracellular $\mathrm{Ca}^{2+}$ as compared to a $58.0 \pm 3.7 \mathrm{nM}$ increase with vehicle treatment alone $(\mathrm{p}<0.001)$. Pre-treatment of rat cerebral VSMC with active heparinase I resulted in a significant reduction of $\mathrm{A} \beta_{1-40}$-induced $\mathrm{Ca}^{2+}$ influx as compared to pre-treatment with vehicle alone $(91.6 \pm 3.3$ vs. $216.1 \pm 13.0 \mathrm{nM}$, respectively; $\mathrm{p}<0.001$ ), but did not completely return the level of intracellular $\mathrm{Ca}^{2+}$ concentration to that of vehicle treatment alone $(91.6 \pm 3.3 \mathrm{vs}$. $58.0 \pm 3.7 \mathrm{nM}$, respectively; $\mathrm{p}<0.001)$. Notably, pretreatment of rat cerebral VSMC with heat-inactivated heparinase I resulted in an increase in $\mathrm{A} \beta_{1-40}$-induced $\mathrm{Ca}^{2+}$ influx as compared to pre-treatment with active heparinase I $(180.4 \pm 8.4$ vs. $91.6 \pm 3.3 \mathrm{nM}$, respectively; $p<$ 0.001 ). We also found a similar (albeit less pronounced) HSPG-mediated effect of $\mathrm{A} \beta_{1-40}$ on $\mathrm{Ca}^{2+}$ influx in human VSMC (Additional file 9: Figure S8). Collectively, these data suggest that pharmacological interference with HSPG attenuates $A \beta_{1-40}$-induced increases in intracellular $\mathrm{Ca}^{2+}$ in rat and human cerebral VSMC.

To determine whether intracellular $\mathrm{Ca}^{2+}$ influx is required for $A \beta_{1-40}$ and $A \beta_{1-42}$-induced ROS production, we co-incubated rat cerebral VSMC with EGTA and assayed for ROS production after 30 minutes following treatment with either $A \beta_{1-40}$ or $A \beta_{1-42}$. Our results show that $\mathrm{Ca} 2+$ influx may not be essential for either $A \beta_{1-40^{-}}$ or $\mathrm{A} \beta_{1-42}$-induced ROS production as EGTA failed to inhibit amyloid-induced ROS (Fig. 6a). We found that $\mathrm{A} \beta_{1-40}$-mediated ROS production requires incubation of at least $\sim 30$ minutes (Fig. $6 \mathrm{~b}$ ), however, $A \beta_{1-40}$-induced
$\mathrm{Ca}^{2+}$ influx and VSMC hypercontractility occur within 5 minutes following $A \beta_{1-40}$ treatment (Fig. 6c).

\section{Discussion and conclusions}

Our results demonstrate that (1) $A \beta_{1-40}$ and $A \beta_{1-42}$ (but not the scrambled peptide $\left.A \beta_{40-1}\right)$ induce ROS production in cultured human cerebral VSMC in a dose-dependent fashion; (2) $A \beta_{1-40^{-}}$and $A \beta_{1-42^{-}}$induced ROS production is mediated downstream by NADPH oxidase activation, as co-treatment with the NADPH oxidase inhibitor apocynin or co-treatment with siRNA targeting Nox 2 mitigated A $\beta$ induced ROS production in cultured human cerebral VSMC; (3) $A \beta_{1-40^{-}}$and $A \beta_{1-42^{-}}$induced ROS production is mediated via HSPG, as pre-treatment with heparin, heparinase (I and III), and sodium chlorate prevents $\mathrm{A} \beta$ induced ROS production in cultured human cerebral VSMC and knockdown of other GAG family members (as well as antibody-mediated interference with other known $\mathrm{A} \beta$ binding partners on the cell surface) did not recapitulate this protective effect; (4) $A \beta_{1-40}$, but not $A \beta_{1-42}$, induces a hypercontractile phenotype in cultured rat VSMC-an effect that is dependent on HSPG but not $\mathrm{NADPH}$ oxidase, as $\mathrm{A} \beta_{1-40}$-induced VSMC hypercontractility was reversed when cells were pre-incubated with heparinase I but not when cells were co-treated with apocynin; and (5) $A \beta_{1-40}$, but not $A \beta_{1-42}$, induces HSPGdependent $\mathrm{Ca}^{2+}$ influx that appears to underlie the pathologic effect of $A \beta_{1-40}$ on VSMC function, as $A \beta_{1-40}$ causes $\mathrm{Ca}^{2+}$ influx into cultured rat VSMC that coincides temporally with $A \beta_{1-40}$-induced VSMC hypercontractility. Importantly, both $A \beta_{1-40}$-induced VSMC dysfunction and $\mathrm{A} \beta_{1-40}$-induced $\mathrm{Ca}^{2+}$ influx appear mediated via HSPG, as pre-incubation with heparinase I attenuated both events. Overall, our data not only confirm past studies that show

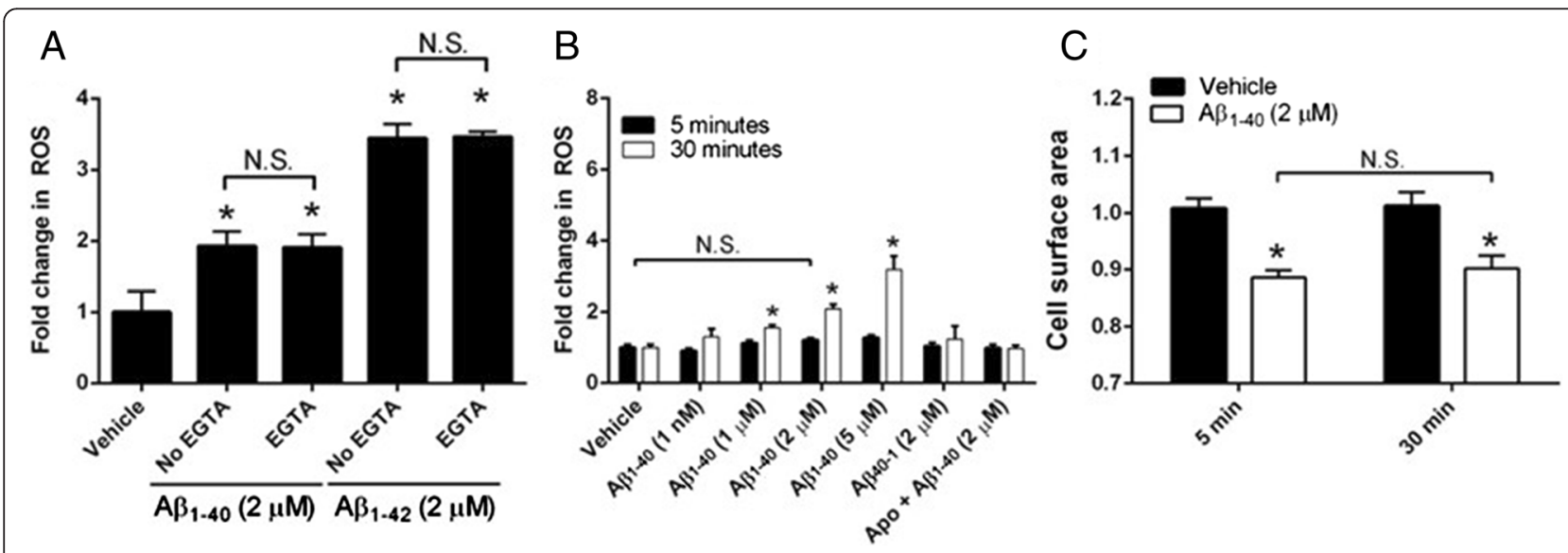

Fig. $6 A \beta_{1-40}$ and $A \beta_{1-42}$-mediated ROS production is not dependent on intracellular $C a^{2+}$ influx. Transformed rat cerebral VSMC were loaded with Mitotracker Red $C M-H_{2} X \operatorname{Ros}(5 \mu M)$ and treated with either $A \beta_{1-40}$ or $A \beta_{1-42}$ in the presence or absence of EGTA (5 mM) in the extracellular media (panel a). A $\beta_{1-40}$-mediated ROS production in VSMC was measured after 5 minutes and compared with ROS production after 30 minutes (panel b). A $\beta_{1-40}$-mediated changes in VSMC surface area were measured after 5 minutes and compared with VSMC surface area after 30 minutes (panel c) 
$A \beta$ species induce vascular oxidative stress via NADPH oxidase, but extend upon them by shedding important mechanistic insight into the upstream molecular events by which $A \beta$-induced ROS production and $A \beta$-induced VSMC dysfunction occur. Specifically, our data strongly implicate HSPG as a key mediator of $A \beta_{1-40^{-}}$and $A \beta_{1-42^{-}}$ induced VSMC oxidative stress, $A \beta_{1-40}$-induced VSMC hypercontractility, and $\mathrm{A} \beta_{1-40}$-induced $\mathrm{Ca}^{2+}$ influx (Fig. 7).

These results are important for a number of reasons. First, multiple lines of evidence indicate that vascular pathologies including $A \beta$ have significant and independent contributions to the dementia of $\mathrm{AD}$, a realization that has led the American Heart Association [54], the Alzheimer's Association [55], and the National Institute on Neurological Disorders and Stroke [56] to prioritize studies investigating the nature and mechanisms of vascular contributors to dementia. Second, while oxidative stress has been linked to the $\mathrm{CV}$ dysfunction caused by $\mathrm{A} \beta$ species in a variety of in vitro [13], ex vivo [13], and in vivo [4-7, 17-19] experimental paradigms, the upstream molecular events leading to this vascular oxidative stress are poorly understood. Identification of these events would likely lead to discovery of novel molecules that that could serve as new therapeutic targets for patients with $\mathrm{AD}$, CAA, or both. Our results implicating HSPG as a key mediator of $A \beta$-induced oxidative stress and $A \beta_{1-40}$-induced VSMC dysfunction strongly suggest that this cell surface molecular complex represents a new pharmacologic target deserving of additional investigation. Third, while our study concentrated on the pathologic effects of two

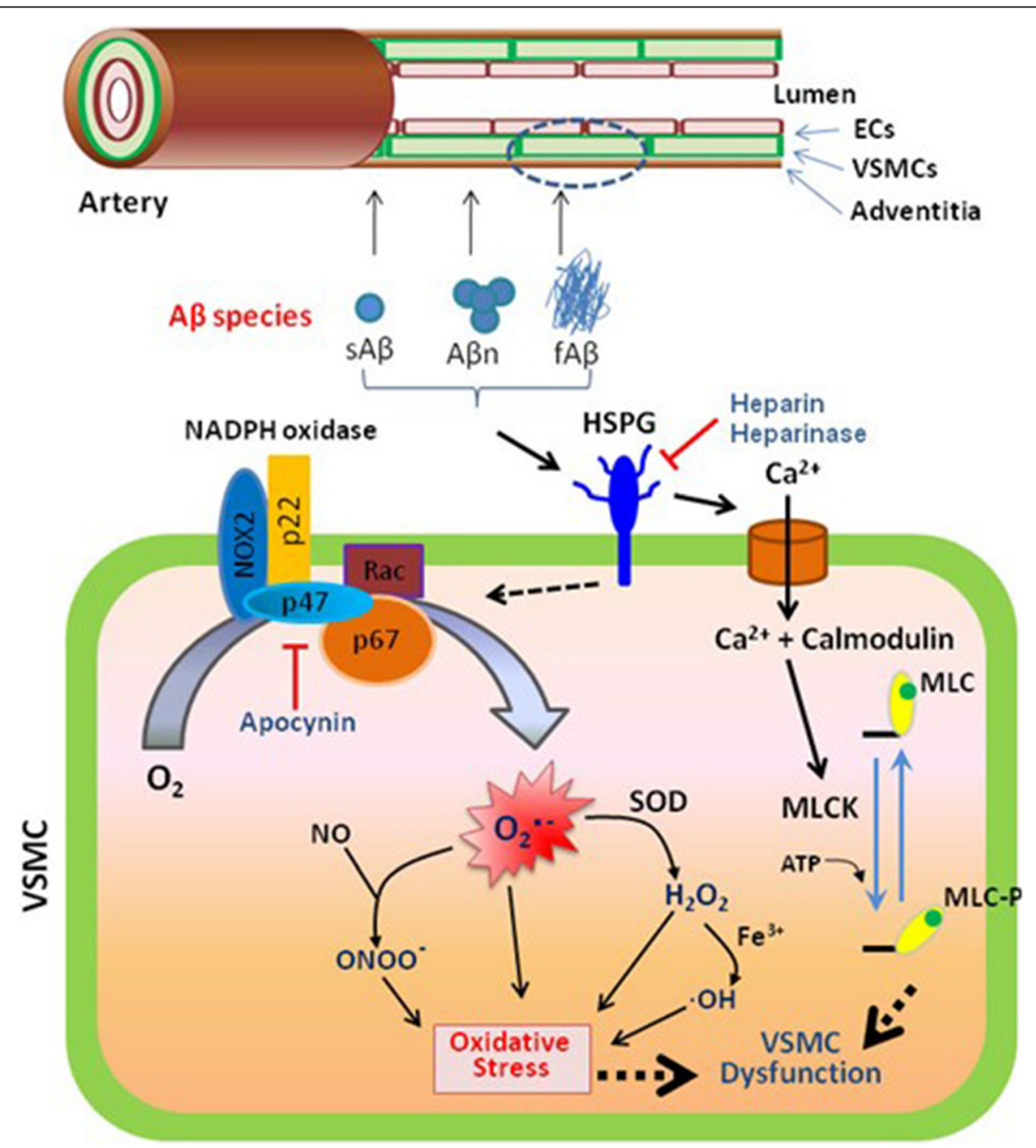

Fig. 7 Schematic illustrating the cascade of intracellular events culminating in A -induced $\mathrm{Ca}^{2+}$ influx, ROS production, and VSMC contractility. A (in either monomeric, oligomeric, or fibrillar form) may interact with cell surface or extracellular matrix HSPG, leading to intracellular $\mathrm{Ca}^{2+}$ influx (early event, $\sim 2$ mins) and ROS production (later event, $\sim 30$ mins). Toxic ROS species may directly damage the VSMC contractile machinery leading to a hypercontractile phenotype. Also, via an independent or interdependent pathway, intracellular $\mathrm{Ca}^{2+}$ may bind to calmodulin to activate myosin light chain kinase (MLCK) and facilitate VSMC contraction. Interference with AB-HSPG binding via treatment with heparin or heparinase can mitigate these toxic effects of $A \beta$ 
monomeric forms of $A \beta\left(A \beta_{1-40}\right.$ and $\left.A \beta_{1-42}\right)$ on one vascular cell type (VSMC), our results may well have mechanistic implications on other forms of $\mathrm{A} \beta$-induced $\mathrm{CV}$ dysfunction including that caused by vascular endothelial cell (VEC) dysfunction and that caused by higher order A $\beta$ species. Support for the former comes from in vitro, ex vivo, and in vivo studies that implicate ROS in $A \beta-$ induced VEC dysfunction [13, 17, 57] and VEC-mediated vasomotor impairment; [13, 17, 57-59] support for the latter comes from in vitro and in vivo studies demonstrating that oligomeric $A \beta$ (at least in neurons) [60] and fibrillar $A \beta$ (in cerebral vessels and neurons) $[18,61-65]$ cause even greater degrees of oxidative stress. Therefore, while elevated levels of soluble $A \beta$-and their attendant vascular consequences including altered $\mathrm{CV}$ reactivity [6] and impaired CBF $[49,50]$-are present in the early stages of $\mathrm{AD}$ when fibrillar $\mathrm{A} \beta$ in the form of neuritic plaques and CAA have yet to develop to a significant degree, the mechanisms elucidated in our study may very well exert their greatest impact on the later stages of $\mathrm{AD}$ when higher order $A \beta$ species are much more abundant. Future studies will be required to examine this intriguing possibility.

One interesting and at first counterintuitive observation from our results is that while exogenous $A \beta_{1-42}$ application induces ROS production somewhat more effectively than $A \beta_{1-40}$ in cultured human and rat VSMC, only $A \beta_{1-40}$ generates a hypercontractile phenotype in rat VSMC. The most plausible explanation for this finding is that $A \beta_{1-40}$ induces an influx of intracellular $\mathrm{Ca}^{2+}$ much more effectively than $A \beta_{1-42}$ (a notion supported by our data; see Figs. 5 and 6 ), and that $A \beta$-mediated ROS production and $\mathrm{A} \beta$-mediated $\mathrm{Ca}^{2+}$ influx may contribute to $\mathrm{CV}$ dysfunction via independent, or interdependent, processes. Our data support a scenario whereby $A \beta$ monomers interact with cell surface and/or extracellular matrix HSPG leading to an early intracellular $\mathrm{Ca}^{2+}$ influx $(\sim 2 \mathrm{~min})$ and a later elaboration of ROS species ( 30 min) (Fig. 6). These toxic ROS may subsequently direct damage to the VSMC contractile machinery, thereby leading to a hypercontractile phenotype. In addition, through an independent or interdependent process, intracellular $\mathrm{Ca}^{2+}$ may contribute to A $\beta$-induced VSMC dysfunction by binding to calmodulin and activate myosin light chain kinase to facilitate VSMC contraction (Fig. 7). Determining which of these two processes is the primary driver of A $\beta$-induced VSMC dysfunction, and assessing whether either process is dependent on the other will require additional experiments. However, our initial studies indicate the following: 1$) \mathrm{Ca} 2+$ influx does not appear necessary for either $A \beta_{1-40^{-}}$or $A \beta_{1-42^{-}}$induced ROS production in VSMC (Fig. 6a); and 2) $\mathrm{A} \beta_{1-40^{-}}$ induced VSMC hypercontractility appears to temporally coincide with $\mathrm{A} \beta_{1-40}$-induced $\mathrm{Ca}^{2+}$ influx and precede significant $A \beta_{1-40}$-mediated ROS production (Fig. 6b, c). As such, it may be that intracellular $\mathrm{Ca}^{2+}$ activity-rather than intracellular $\mathrm{ROS}-\mathrm{is}$ the primary driver $\mathrm{A} \beta_{1-40}$-induced VSMC dysfunction.

That interference with A $\beta$-HSPG binding via treatment with heparin, heparinase, or sodium chlorate mitigated both of these $A \beta$-induced toxic effects argues strongly for the concept that HSPG-directed therapies carry promise as a new approach towards combating the consequences of $\mathrm{A} \beta$-induced $\mathrm{CV}$ dysfunction in patients with $\mathrm{AD}, \mathrm{CAA}$, or both. Another interesting observation from our data was that apocynin co-treatment of VSMC reduced A $\beta$ mediated ROS production (Fig. 1) but did not rescue these cells from a hypercontractile phenotype (Fig. 4). These data seem to conflict with our prior observation in explanted rat cerebral arterioles that strategies aimed to reduce ROS were effective in reversing the $A \beta$-mediated hypercontractile response [13]. Most likely, this observation relates to the differing experimental models utilized in our two studies. In the present report, we utilized isolated VSMC monocultures that permit direct measurement of VSMC function, while in our former study [13] we employed isolated cerebral arterioles that permit assessment of both VEC-dependent as well as VECindependent vasomotor function. It is plausible that $A \beta$ mediated ROS production has a greater functional impact on VEC than on VSMC, which explain our [13] and others $[17,19]$ past findings that vascular oxidative stress is an important mediator of $\mathrm{A} \beta$-induced $\mathrm{CV}$ dysfunction in the setting of intact vessels (ex vivo and in vivo).

Our study has several limitations. First, our experiments were performed in tissue culture and may not be generalized to the ex vivo or in vivo settings. Second, our experiments focused solely on the role of $A \beta$ mediated toxic effects in cultured VSMC. To address both of these limitations, we are currently performing experiments to determine the role of HSPG in the oxidative stress and functional consequences of $A \beta$ in cultured VEC and $A \beta$ applied to isolated cerebral vessels. Third, while fibrillar $A \beta$ in the form of CAA is commonly present in the smooth muscle cell layer of cerebral arterioles, it is possible that monomeric $A \beta$ may not be present in this compartment at $\mu \mathrm{M}$ concentrations. While the concentration of $A \beta$ in the serum and cerebrospinal fluid has been estimated in the $\mathrm{nM}$ range [66], recent evidence suggests soluble $A \beta$ species are in a dynamic equilibrium with fibrillar $A \beta$ deposits in brain and cerebral vessels [35] which would allow for higher local concentrations of $A \beta$ in brain regions immediately surrounding fibrillar $A \beta$ deposits. Therefore, it is entirely possible that the local concentration of monomeric $A \beta$ in the perivascular space is significantly higher (e.g., $\mu \mathrm{M}$, or even $\mathrm{mM}$ ), thereby validating the physiological relevance of the $A \beta$ concentrations that we chose for our experiments. 


\section{Additional files}

Additional file 1: Table S1. Heparin sulfate proteoglycan (HSPG) primer pairs for quantitative polymerase chain reaction (qPCR). (DOCX $20 \mathrm{~kb}$ )

Additional file 2: Figure S1. Soluble, monomeric $A \beta_{1-40}$ induces lipid oxidation in human VSMC. Human VSMC were exposed to $A \beta_{1-40}$ for $24 \mathrm{~h}$, followed by assessment of lipid oxidation via measurement of thiobarbituric acid reactive substance (TBARS). In parallel experiments primary human cerebral VSMC were also pre-treated with heparinase I (Hpnl; 5 Sigma U/mL). Results are representative of 3 independent experiments performed in triplicate. ${ }^{*} p<0.05$ vs. vehicle-treated control. $\# p<0.05$ vs. comparison group. (JPEG $28 \mathrm{~kb}$ )

Additional file 3: Figure S2. Apocynin does not impact baseline ROS production in VSMC. Human VSMC were loaded with Mitotracker Red $\mathrm{CM}-\mathrm{H}_{2} \mathrm{XRos}(5 \mu \mathrm{M})$ and treated with $\mathrm{A} \beta_{1-40}$. In some cases, cells were co-treated with the NADPH oxidase inhibitor apocynin (Apo; $10 \mu \mathrm{M})$. Fluorescence was measured after 30 minutes. Results are representative of 3 independent experiments performed in triplicate. ${ }^{*} p<0.05$ vs. vehicle-treated control. \#p $<0.05$ vs. comparison group. (JPEG 31 kb)

Additional file 4: Figure S3. HSPG mitigates $A \beta_{1-40}$-induced mitochondrial and cytosolic ROS production in VSMC under physiological oxygen concentration. To determine if differing levels oxygen impact ROS production in $A \beta_{1-40}$ treated VSMC, cells were kept in $10 \%$ oxygen (Panel A) or $1 \%$ oxygen (conditions that are considered hypoxic; Panel B) in cell culture incubator with $\% 5 \mathrm{CO}_{2}$. Primary human cerebral VSMC were pre-treated with heparin $(15 \mathrm{U} / \mathrm{mL})$, heparinase I (Hpnl; 5 Sigma U/ $\mathrm{mL}$ ), or heparinase III (HpnIIl; 2 Sigma $U / \mathrm{mL}$ ) for $2 \mathrm{~h}$, washed, loaded with Mitotracker Red $\mathrm{CM}-\mathrm{H}_{2} \mathrm{XRos}$, washed, and treated with $\mathrm{A} \beta_{1-40}$. In some cases, cells were pre-treated with heat-inactivated $(\mathrm{HI})$ enzyme. Fluorescence was measured after 30 minutes. Results are representative of 3 independent experiments performed in triplicate. ${ }^{*} p<0.05$ vs. vehicle-treated control. $\# p<0.05$ vs. comparison group. (JPEG $70 \mathrm{~kb}$ )

Additional file 5: Figure S4. $A \beta_{1-40}$ and $A \beta_{1-42}$ remain mostly in soluble, monomeric form after 30 minute incubation in L-15 media. Conditioned media from $A \beta_{1-40^{-}}$(panels $A, B$ ) and $A \beta_{1-42}$-treated VSMC $(5 \mu M)$ was loaded onto a size exclusion column and fractionated via fast performance liquid chromatography (FPLC). A $\beta$-containing fractions were identified using enzyme-linked immunosorbent assays (ELISA) and higher-order $A \beta$ species were separated from monomer (4 kDa) by SDS- (panels A, C) and native(panels B, D) polyacrylamide gel electrophoresis (PAGE) with Western blotting. $A \beta_{1-40}$ and $A \beta_{1-42}$ peptides were detected using the anti-Human A $\beta$ mouse $82 E 1$ monoclonal antibody $(1 \mu \mathrm{g} / \mathrm{mL})$. To specifically differentiate monomers vs. oligomers in the media, we performed dot blot using oligomer-specific anti- A $\beta$ antibody (A11; Panel E). (JPEG 75 kb)

Additional file 6: Figure S5. HSPG subtype mRNA is present in primary human cerebral and transformed rat cerebral VSMC. HSPG subtype mRNA was harvested from primary human cerebral as well as transformed rat cerebral VSMC and measured using quantitative polymerase chain reaction ( $q P C R$ ). Extracellular matrix HSPG include agrin, perlecan, and collagen XVIII; cell surface HSPG include glypicans 1-6 and syndecans 1-4 (Panel A). In addition we also performed qPCR for chondroitin sulphate, dermatan sulphate and keratan sulfate (Panel B). ${ }^{*} p<0.05$ vs. comparison group. (JPEG $90 \mathrm{~kb}$ )

Additional file 7: Figure S6. Human VSMC cells from second source conform that HSPG mitigates $A \beta_{1-40}$-induced mitochondrial and cytosolic ROS production in VSMC. Primary human cerebral VSMC from other source (Cell Biologics, Chicago, IL) were pre-treated with heparin $(15 \mathrm{U} / \mathrm{mL}$ ), heparinase I (Hpnl; 5 Sigma U/mL), or heparinase III (HpnIII; 2 Sigma U/mL) for $2 \mathrm{~h}$, washed, loaded with Mitotracker Red CM-H $\mathrm{H}_{2}$ XRos (MTR; $5 \mu \mathrm{M}$ ), washed, and treated with $A \beta_{1-40}$. In some cases, cells were pre-treated with heat-inactivated $(\mathrm{HI})$ enzyme. Fluorescence was measured after 30 minutes. Results are representative of 3 independent experiments performed in triplicate. ${ }^{*} p<0.05$ vs. vehicle-treated control. $\# p<0.05$ vs. comparison group. (JPEG $42 \mathrm{~kb}$ )

Additional file 8: Figure S7. Transformed rat cerebral VSMC behave similarly to human cerebral VSMC with respect to $A \beta_{1-40}$-induced ROS production and mitigation of $A \beta_{1-40}$-induced oxidative stress by pharmacological knockdown of HSPG with heparinase. Rat cerebral VSMC were loaded with Mitotracker Red $\mathrm{CM}-\mathrm{H}_{2}$ XRos $(5 \mu \mathrm{M})$ and treated with varying concentrations of $A \beta_{1-40}$ or a scrambled control peptide $\left(A \beta_{40-1}\right.$; panel A). In some experiments, cells were pre-treated with heparinase (or heat-inactivated enzyme) for $2 \mathrm{~h}$, washed, and then treated with $A \beta_{1-40}(2 \mu \mathrm{M})$ (panel B). Fluorescence was measured after 30 minutes. Results are representative of 3 independent experiments performed in triplicate. $\mathrm{Apo}=$ apocynin. $\mathrm{Hpn}=$ heparinase. $\mathrm{HI}=$ heat inactivated. ${ }^{*} p<0.05$ vs. vehicle-treated control. \#p < 0.05 vs. comparison group. (JPEG $56 \mathrm{~kb}$ )

Additional file 9: Figure S8. Human VSMC cells also show $A \beta_{1-40}$ induces HSPG-mediated $\mathrm{Ca}^{2+}$ influx. Primary human VSMC were loaded with fura II (10 $\mu \mathrm{M})$ and treated with varying concentrations of $A \beta_{1-40}$. In some experiments, cells were pre-treated with active heparinase I ( $\mathrm{Hpnl}$; 5 Sigma $U / m L$ ), washed, loaded with fura II, and treated with $A \beta_{1-40}$. Fluorescence was measured over $\sim 10$ minutes. Results are representative of 3 independent experiments performed in triplicate. ${ }^{*} p<0.05$ vs. vehicle-treated control. (JPEG $44 \mathrm{~kb}$ )

\section{Abbreviations}

AD: Alzheimer's disease; A 3 : Amyloid Beta; CAA: cerebral amyloid angiopathy; CBF: cerebral blood flow; CSA: cell surface area; CV: cerebrovascular; DHE: Dihydroethidium; EGTA: ethylene glycol tetraacetic acid; ELISA: enzymelinked immunosorbent assay; FPLC: fast performance liquid chromatography; GAG: glycosaminoglycan; HSPG: heparan sulfate proteoglycans; MTR: mitotracker red $\mathrm{CM}-\mathrm{H} 2 \mathrm{X}$ ros; NADPH oxidase: nicotinamide adenine dinucleotide phosphate-oxidase; PAGE: polyacrylamide gel electrophoresis; qPCR: quantitative polymerase chain reaction; ROS: reactive oxygen species; VEC: vascular endothelial cells; VSMC: vascular smooth muscle cells.

\section{Competing interests}

The authors declare that they have no competing interests.

\section{Authors' contributions}

Conception and design: MRR and GJZ. Acquisition of data: MRR, IS, TDA, and PBV. Analysis and interpretation of data: All authors. Drafting of initial manuscript: MRR. Critical revisions of manuscript: All authors. All authors read and approved the final manuscript.

\section{Acknowledgments}

The authors would like to acknowledge Drs. David Holtzman (Washington University in St. Louis, MO) and William Frazier (Washington University in St. Louis, MO) for helpful discussions and materials.

\section{Funding}

This work was supported by grants from the National Institutes of Health (R01 NS071011 to G.J.Z; RF1AG051504, R01AG027924, P01NS074969 and P50AG016574 to G.B.), American Health Assistance Foundation (B.H.H. and G.J.Z.), Alzheimer's Association (G.B.), and Harrington/Zhu Alzheimer Research Fund (G.J.Z.).

\section{Author details}

${ }^{1}$ Department of Neurological Surgery, Washington University School of Medicine, Hope Center Program on Protein Aggregation and Neurodegeneration, Charles F. and Joanne Knight Alzheimer's Disease Research Center, Campus Box 8057, 660 South Euclid Avenue, St. Louis, Missouri 63110, USA. ²Department of Neurology, Washington University School of Medicine, Hope Center Program on Protein Aggregation and Neurodegeneration, Charles F. and Joanne Knight Alzheimer's Disease Research Center, St. Louis, Missouri, USA. ${ }^{3}$ Center for Alzheimer's and Neurodegenerative Diseases, UT Southwestern, Dallas, Texas, USA. ${ }^{4}$ Department of Neuroscience, Mayo Clinic, Jacksonville, Florida, USA. ${ }^{5}$ Department of Pharmacology, AT Still University Health Sciences, Kirksville, Missouri, USA

Received: 3 February 2015 Accepted: 12 January 2016

Published online: 22 January 2016

\section{References}

1. Selkoe DJ. The cell biology of $\beta$-amyloid precursor protein and presenilin in Alzheimer's disease. Trends Cell Biol. 1998;8(11):447-53. 
2. Zipfel GJ, Han H, Ford AL, Lee J-M. Cerebral amyloid angiopathy progressive disruption of the neurovascular unit. Stroke. 2009;40(3 suppl 1):S16-9.

3. Shin HK, Jones PB, Garcia-Alloza M, Borrelli L, Greenberg SM, Bacskai BJ, et al. Age-dependent cerebrovascular dysfunction in a transgenic mouse model of cerebral amyloid angiopathy. Brain. 2007;130(9):2310-9.

4. Hamel E. The cerebral circulation: function and dysfunction in Alzheimer's disease. J Cardiovasc Pharmacol. 2014.

5. Nicolakakis N, Hamel E. Neurovascular function in Alzheimer's disease patients and experimental models. J Cereb Blood Flow Metab. 2011;31(6):1354-70.

6. Han BH, Zhou M-I, Abousaleh F, Brendza RP, Dietrich HH, KoenigsknechtTalboo J, et al. Cerebrovascular dysfunction in amyloid precursor protein transgenic mice: contribution of soluble and insoluble amyloid- $\beta$ peptide, partial restoration via $\gamma$-secretase inhibition. J Neurosci. 2008;28(50):13542-50.

7. Park L, Koizumi K, El Jamal S, Zhou P, Previti ML, Van Nostrand WE, et al. Age-dependent neurovascular dysfunction and damage in a mouse model of cerebral amyloid angiopathy. Stroke. 2014;45(6):1815-21.

8. Park L, Zhou P, Koizumi K, El Jamal S, Previti ML, Van Nostrand WE, et al. Brain and circulating levels of $A \beta 1-40$ differentially contribute to vasomotor dysfunction in the mouse brain. Stroke. 2013;44(1):198-204.

9. Milner E, Zhou M-L, Johnson AW, Vellimana AK, Greenberg JK, Holtzman DM, et al. Cerebral amyloid angiopathy increases susceptibility to infarction after focal cerebral ischemia in Tg2576 mice. Stroke. 2014;45(10):3064-9.

10. Zhang F, Eckman C, Younkin S, Hsiao KK, ladecola C. Increased susceptibility to ischemic brain damage in transgenic mice overexpressing the amyloid precursor protein. J Neurosci. 1997;17(20):7655-61.

11. Koistinaho M, Kettunen Ml, Goldsteins G, Keinänen R, Salminen A, Ort M, et al. Beta-amyloid precursor protein transgenic mice that harbor diffuse Abeta deposits but do not form plaques show increased ischemic vulnerability: role of inflammation. Proc Natl Acad Sci U S A. 2002:99:1610-5.

12. ladecola C, Park L, Capone C. Threats to the mind aging, amyloid, and hypertension. Stroke. 2009;40(3 suppl 1):S40-4.

13. Dietrich $H H$, Xiang $C$, Han BH, Zipfel GJ, Holtzman DM. Soluble amyloid- $\beta$, effect on cerebral arteriolar regulation and vascular cells. Mol Neurodegener. 2010;5(1):15.

14. Price JM, Sutton ET, Hellermann A, Thomas T. beta-Amyloid induces cerebrovascular endothelial dysfunction in the rat brain. Neurol Res. 1997;19(5):534-8.

15. Park L, Anrather J, Forster C, Kazama K, Carlson GA, ladecola C. A -induced vascular oxidative stress and attenuation of functional hyperemia in mouse somatosensory cortex. J Cereb Blood Flow Metab. 2004;24(3):334-42.

16. Niwa K, Carlson GA, ladecola C. Exogenous Ab1-40 reproduces cerebrovascular alterations resulting from amyloid precursor protein overexpression in mice. J Cereb Blood Flow Metab. 2000;20(12):1659-68.

17. Park L, Anrather J, Zhou P, Frys K, Pitstick R, Younkin S, et al. NADPH oxidasederived reactive oxygen species mediate the cerebrovascular dysfunction induced by the amyloid $\beta$ peptide. J Neurosci. 2005;25(7):1769-77.

18. Garcia-Alloza M, Prada C, Lattarulo C, Fine S, Borrelli LA, Betensky R, et al. Matrix metalloproteinase inhibition reduces oxidative stress associated with cerebral amyloid angiopathy in vivo in transgenic mice. J Neurochem. 2009; 109(6):1636-47.

19. Park L, Zhou P, Pitstick R, Capone C, Anrather J, Norris EH, et al. Nox2-derived radicals contribute to neurovascular and behavioral dysfunction in mice overexpressing the amyloid precursor protein. Proc Natl Acad Sci. 2008; 105(4):1347-52

20. Hsiao K, Chapman P, Nilsen S, Eckman C, Harigaya Y, Younkin S, et al. Correlative memory deficits, $A \beta$ elevation, and amyloid plaques in transgenic mice. Science. 1996;274(5284):99-103.

21. Han BH, Zhou M-I, Johnson AW, Singh I, Liao F, Vellimana AK, et al. Contribution of reactive oxygen species to cerebral amyloid angiopathy, vasomotor dysfunction, and microhemorrhage in aged Tg2576 mice. Proc Natl Acad Sci U S A. 2015;112(8):E881-890.

22. van Horssen J, Wesseling P, van Den Heuvel LP, De Waal RM, Verbeek MM. Heparan sulphate proteoglycans in Alzheimer's disease and amyloid-related disorders. Lancet Neurol. 2003;2(8):482-92

23. Snow A, Mar H, Nochlin D, Sekiguchi R, Kimata K, Koike Y, et al. Early accumulation of heparan sulfate in neurons and in the beta-amyloid protein-containing lesions of Alzheimer's disease and Down's syndrome. Am J Pathol. 1990;137(5):1253.

24. van Horssen J, Otte-Höller I, David G, Maat-Schieman ML, Heuvel LP, Wesseling $\mathrm{P}$, et al. Heparan sulfate proteoglycan expression in cerebrovascular amyloid $\beta$ deposits in Alzheimer's disease and hereditary cerebral hemorrhage with amyloidosis (Dutch) brains. Acta Neuropathol. 2001;102(6):604-14.

25. Castillo GM, Ngo C, Cummings J, Wight TN, Snow AD. Perlecan binds to the $\beta$-amyloid proteins (A $\beta$ ) of Alzheimer's disease, accelerates $A \beta$ fibril formation, and maintains $A \beta$ fibril stability. J Neurochem. 1997;69(6):2452-65.

26. Cotman SL, Halfter W, Cole GJ. Agrin binds to $\beta$-amyloid (AB), accelerates $A \beta$ fibril formation, and is localized to $A \beta$ deposits in Alzheimer's disease brain. Mol Cell Neurosci. 2000;15(2):183-98.

27. Sandwall E, O'Callaghan P, Zhang X, Lindahl U, Lannfelt L, Li J-P. Heparan sulfate mediates amyloid-beta internalization and cytotoxicity. Glycobiology. 2010;20(5):533-41.

28. Kanekiyo T, Bu G. Receptor-associated protein interacts with amyloid- $\beta$ peptide and promotes its cellular uptake. J Biol Chem. 2009;284(48):33352-9.

29. Kanekiyo T, Zhang J, Liu Q, Liu C-C, Zhang L, Bu G. Heparan sulphate proteoglycan and the low-density lipoprotein receptor-related protein 1 constitute major pathways for neuronal amyloid- $\beta$ uptake. J Neurosci. 2011;31(5):1644-51.

30. Li J-P, Galvis MLE, Gong F, Zhang X, Zcharia E, Metzger S, et al. In vivo fragmentation of heparan sulfate by heparanase overexpression renders mice resistant to amyloid protein A amyloidosis. Proc Natl Acad Sci U S A. 2005;102(18):6473-7.

31. Iadecola C. Cerebrovascular effects of amyloid-ß peptides: mechanisms and implications for Alzheimer's dementia. Cell Mol Neurobiol. 2003;23(4-5):681-9.

32. Gahr M, Nowak DA, Connemann BJ, Schönfeldt-Lecuona C. Cerebral amyloidal angiopathy - a disease with implications for neurology and psychiatry. Brain Res. 2013;1519:19-30.

33. Attems J, Jellinger K, Thal D, Van Nostrand W. Review: sporadic cerebral amyloid angiopathy. Neuropathol Appl Neurobiol. 2011;37(1):75-93.

34. Christie R, Yamada M, Moskowitz M, Hyman B. Structural and functional disruption of vascular smooth muscle cells in a transgenic mouse model of amyloid angiopathy. Am J Pathol. 2001;158(3):1065-71.

35. Koffie RM, Meyer-Luehmann M, Hashimoto T, Adams KW, Mielke ML, Garcia-Alloza M, et al. Oligomeric amyloid $\beta$ associates with postsynaptic densities and correlates with excitatory synapse loss near senile plaques. Proc Natl Acad Sci. 2009;106(10):4012-17.

36. Diglio CA, Grammas $P$, Giacomelli F, Wiener J. Rat cerebral microvascular smooth muscle cells in culture. J Cell Physiol. 1986;129(2):131-41.

37. Diglio CA, Wolfe DE, Meyers P. Transformation of rat cerebral endothelial cells by Rous sarcoma virus. J Cell Biol. 1983;97(1):15-21.

38. Grynkiewicz G, Poenie M, Tsien RY. A new generation of $\mathrm{Ca} 2+$ indicators with greatly improved fluorescence properties. J Biol Chem. 1985;260(6):3440-50.

39. Poenie M, Alderton J, Steinhardt R, Tsien R. Calcium rises abruptly and briefly throughout the cell at the onset of anaphase. Science. 1986;233(4766):886-9.

40. Batlle DC, Peces R, LaPointe MS, Ye M, Daugirdas JT. Cytosolic free calcium regulation in response to acute changes in intracellular $\mathrm{pH}$ in vascular smooth muscle. Am J Physiol. 1993;264:C932-2.

41. Dietrich HH, Kimura M, Dacey Jr RG. Nw-nitro-L-arginine constricts cerebral arterioles without increasing intracellular calcium levels. Am J Physiol. 1994;266(35):H1681-6.

42. Shinohara M, Petersen RC, Dickson DW, Bu G. Brain regional correlation of amyloid- $\beta$ with synapses and apolipoprotein $E$ in non-demented individuals: potential mechanisms underlying regional vulnerability to amyloid- $\beta$ accumulation. Acta Neuropathol. 2013;125(4):535-47.

43. Livak KJ, Schmittgen TD. Analysis of relative gene expression data using real-time quantitative PCR and the $2^{-D D C T}$ method. Methods. 2001;25(4):402-8.

44. Crawford F, Suo Z, Fang C, Mullan M. Characteristics of the in vitro vasoactivity of $\beta$-amyloid peptides. Exp Neurol. 1998;150(1):159-68.

45. Sullivan M, Galea P, Latif $\mathrm{S}$. What is the appropriate oxygen tension for in vitro culture? Mol Hum Reprod. 2006;12(11):653.

46. Bergamaschini L, Rossi E, Storini C, Pizzimenti S, Distaso M, Perego C, et al. Peripheral treatment with enoxaparin, a low molecular weight heparin, reduces plaques and $\beta$-amyloid accumulation in a mouse model of Alzheimer's disease. J Neurosci. 2004;24(17):4181-6.

47. Holmes BB, DeVos SL, Kfoury N, Li M, Jacks R, Yanamandra K, et al. Heparan sulfate proteoglycans mediate internalization and propagation of specific proteopathic seeds. Proc Natl Acad Sci U S A. 2013;110(33):E3138-3147.

48. Brunden KR, Richter-Cook NJ, Chaturvedi N, Frederickson RC. pH-dependent binding of synthetic $\beta$-amyloid peptides to glycosaminoglycans. J Neurochem. 1993;61(6):2147-54. 
49. Niwa K, Kazama K, Younkin L, Younkin SG, Carlson GA, ladecola C. Cerebrovascular autoregulation is profoundly impaired in mice overexpressing amyloid precursor protein. Am J Physiol Heart Circ Physiol. 2002;283(1):H315-23.

50. Niwa K, Younkin L, Ebeling C, Turner SK, Westaway D, Younkin S, et al. $A \beta 1-40$-related reduction in functional hyperemia in mouse neocortex during somatosensory activation. Proc Natl Acad Sci. 2000;97(17):9735-40.

51. Niwa K, Porter VA, Kazama K, Cornfield D, Carlson GA, ladecola C. $A \beta$-peptides enhance vasoconstriction in cerebral circulation. Am J Physiol Heart Circ Physiol. 2001;281(6):H2417-24.

52. Paris D, Humphrey J, Quadros A, Patel N, Crescentini R, Crawford F, et al. Vasoactive effects of $A \beta$ in isolated human cerebrovessels and in a transgenic mouse model of Alzheimer's disease: role of inflammation. Neurol Res. 2003;25(6):642-51.

53. Ratz PH, Berg KM, Urban NH, Miner AS. Regulation of smooth muscle calcium sensitivity: $\mathrm{KCl}$ as a calcium-sensitizing stimulus. Am J Physiol Cell Physiol. 2005;288(4):C769-83.

54. Gorelick PB, Scuteri A, Black SE, DeCarli C, Greenberg SM, ladecola C, et al. Vascular contributions to cognitive impairment and dementia a statement for healthcare professionals from the American Heart Association/American Stroke Association. Stroke. 2011;42(9):2672-713.

55. Snyder HM, Corriveau RA, Craft S, Faber JE, Greenberg SM, Knopman D, et al. Vascular contributions to cognitive impairment and dementia including Alzheimer's disease. Alzheimers Dement. 2014.

56. Vickrey B, Brott T, Koroshetz W. Stroke research priorities meeting steering committee and the national advisory neurological disorders and stroke council; National Institute of Neurological Disorders and Stroke. Research priority setting: a summary of the 2012 NINDS stroke planning meeting report. Stroke. 2013;44:2338-42.

57. Tong X-K, Nicolakakis N, Kocharyan A, Hamel E. Vascular remodeling versus amyloid $\beta$-induced oxidative stress in the cerebrovascular dysfunctions associated with Alzheimer's disease. J Neurosci. 2005;25(48):11165-74.

58. Nicolakakis N, Aboulkassim T, Ongali B, Lecrux C, Fernandes P, Rosa-Neto P, et al. Complete rescue of cerebrovascular function in aged Alzheimer's disease transgenic mice by antioxidants and pioglitazone, a peroxisome proliferator-activated receptor $\gamma$ agonist. J Neurosci. 2008;28(37):9287-96.

59. Tong $X$, Hamel E. Regional cholinergic denervation of cortical microvessels and nitric oxide synthase-containing neurons in Alzheimer's disease. Neuroscience. 1999;92(1):163-75.

60. De Felice FG, Velasco PT, Lambert MP, Viola K, Fernandez SJ, Ferreira ST, et al. A $\mathrm{B}$ oligomers induce neuronal oxidative stress through an $\mathrm{N}$-methylD-aspartate receptor-dependent mechanism that is blocked by the Alzheimer drug memantine. J Biol Chem. 2007;282(15):11590-601.

61. Garcia-Alloza M, Dodwell SA, Meyer-Luehmann M, Hyman BT, Bacskai BJ. Plaque-derived oxidative stress mediates distorted neurite trajectories in the Alzheimer mouse model. J Neuropathol Exp Neurol. 2006;65(11):1082-9.

62. Dumont M, Wille E, Stack C, Calingasan NY, Beal MF, Lin MT. Reduction of oxidative stress, amyloid deposition, and memory deficit by manganese superoxide dismutase overexpression in a transgenic mouse model of Alzheimer's disease. FASEB J. 2009;23(8):2459-66.

63. Santpere G, Puig B, Ferrer I. Oxidative damage of 14-3-3 zeta and gamma isoforms in Alzheimer's disease and cerebral amyloid angiopathy. Neuroscience. 2007;146(4):1640-51.

64. El Khoury J, Hickman S, Thomas C, Loike J, Silverstein S. Microglia, scavenger receptors, and the pathogenesis of Alzheimer's disease. Neurobiol Aging. 1998;19(1):S81-4.

65. McLellan ME, Kajdasz ST, Hyman BT, Bacskai BJ. In vivo imaging of reactive oxygen species specifically associated with thioflavine S-positive amyloid plaques by multiphoton microscopy. J Neurosci. 2003;23(6):2212-7.

66. Oh ES, Troncoso JC, Tucker SMF. Maximizing the potential of plasma amyloid-beta as a diagnostic biomarker for Alzheimer's disease. Neuromolecular Med. 2008:10(3):195-207.

\section{Submit your next manuscript to BioMed Central and we will help you at every step:}

- We accept pre-submission inquiries

- Our selector tool helps you to find the most relevant journal

- We provide round the clock customer support

- Convenient online submission

- Thorough peer review

- Inclusion in PubMed and all major indexing services

- Maximum visibility for your research

Submit your manuscript at www.biomedcentral.com/submit 